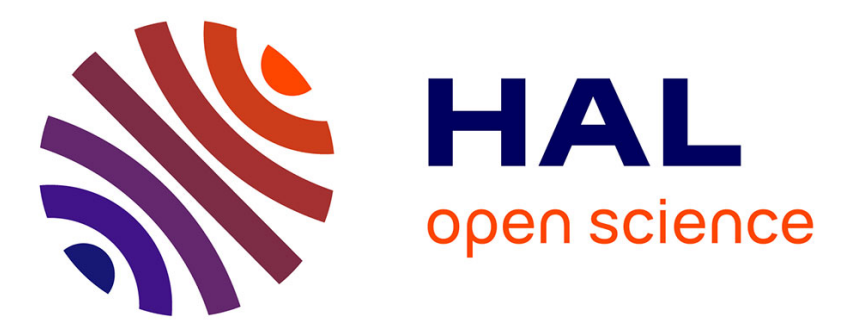

\title{
An innovative implementation of LCA within the EIA procedure: lessons learned from two wastewater treatment plant case studies
}

P. Larrey-Lassalle, L. Catel, P. Roux, R.K. Rosenbaum, Miguel Lopez-Ferber, G. Junqua, Eléonore Loiseau

\section{To cite this version:}

P. Larrey-Lassalle, L. Catel, P. Roux, R.K. Rosenbaum, Miguel Lopez-Ferber, et al.. An innovative implementation of LCA within the EIA procedure: lessons learned from two wastewater treatment plant case studies. Environmental Impact Assessment Review, 2017, 63, pp.95-106. 10.1016/j.eiar.2016.12.004 . hal-02605597

\section{HAL Id: hal-02605597 https: / hal.inrae.fr/hal-02605597}

Submitted on 16 May 2020

HAL is a multi-disciplinary open access archive for the deposit and dissemination of scientific research documents, whether they are published or not. The documents may come from teaching and research institutions in France or abroad, or from public or private research centers.
L'archive ouverte pluridisciplinaire HAL, est destinée au dépôt et à la diffusion de documents scientifiques de niveau recherche, publiés ou non, émanant des établissements d'enseignement et de recherche français ou étrangers, des laboratoires publics ou privés. 


\title{
1 An innovative implementation of LCA within the EIA procedure:
}

2 lessons learned from two wastewater treatment plant case studies

\author{
Pyrène Larrey-Lassalle ${ }^{a, b}$, Laureline Catel ${ }^{a}$, Philippe Roux ${ }^{a}$, Ralph K. Rosenbaum ${ }^{a}$, Miguel \\ Lopez-Ferber ${ }^{b}$, Guillaume Junqua ${ }^{b}$, Eléonore Loiseau ${ }^{a}$ \\ ${ }^{a}$ Irstea, UMR ITAP, ELSA Research group \& ELSA-PACT Industrial Chair for Environmental and Social \\ Sustainability Assessment, 361 rue Jean François Breton, F-34196 Montpellier, France \\ ${ }^{\mathrm{b}}$ LGEI, Ecole des mines d'Alès, 6 avenue de Clavières, 30319 Alès Cedex, France \\ *Corresponding author: pyrene.larrey-lassalle@irstea.fr
}

\section{Highlights}

An innovative methodology for a first-stage implementation of LCA in EIA is proposed.

Its applicability is demonstrated on two wastewater treatment plant case studies.

The conclusions for the four EIA steps investigated differ with or without LCA.

LCA provides valuable additional information on 1) global and 2) off-site impacts.

LCA identifies pollution transfers towards a life cycle perspective.

\section{Abstract}

Life Cycle Assessment (LCA) has been identified in the literature as a promising tool to increase the performance of environmental assessments at different steps in the Environmental Impact Assessment (EIA) procedure. However, few publications have proposed a methodology for an extensive integration, and none have compared the results with existing EIA conclusions without LCA. This paper proposes a comprehensive operational methodology for implementing an LCA within an EIA. Based on a literature review, we identified four EIA steps that could theoretically benefit from LCA implementation, i.e., (a) the environmental comparison of alternatives, (b) the identification of key impacts, (c) the impact assessment, and (d) the impact of mitigation measures. For each of these steps, an LCA was implemented with specific goal and scope definitions that resulted in a specific set of indicators. This approach has been implemented in two contrasting Wastewater Treatment Plant (WWTP) projects and compared to existing EIA studies. The results showed that the two procedures, i.e., EIAs with or without inputs from LCA, led to 


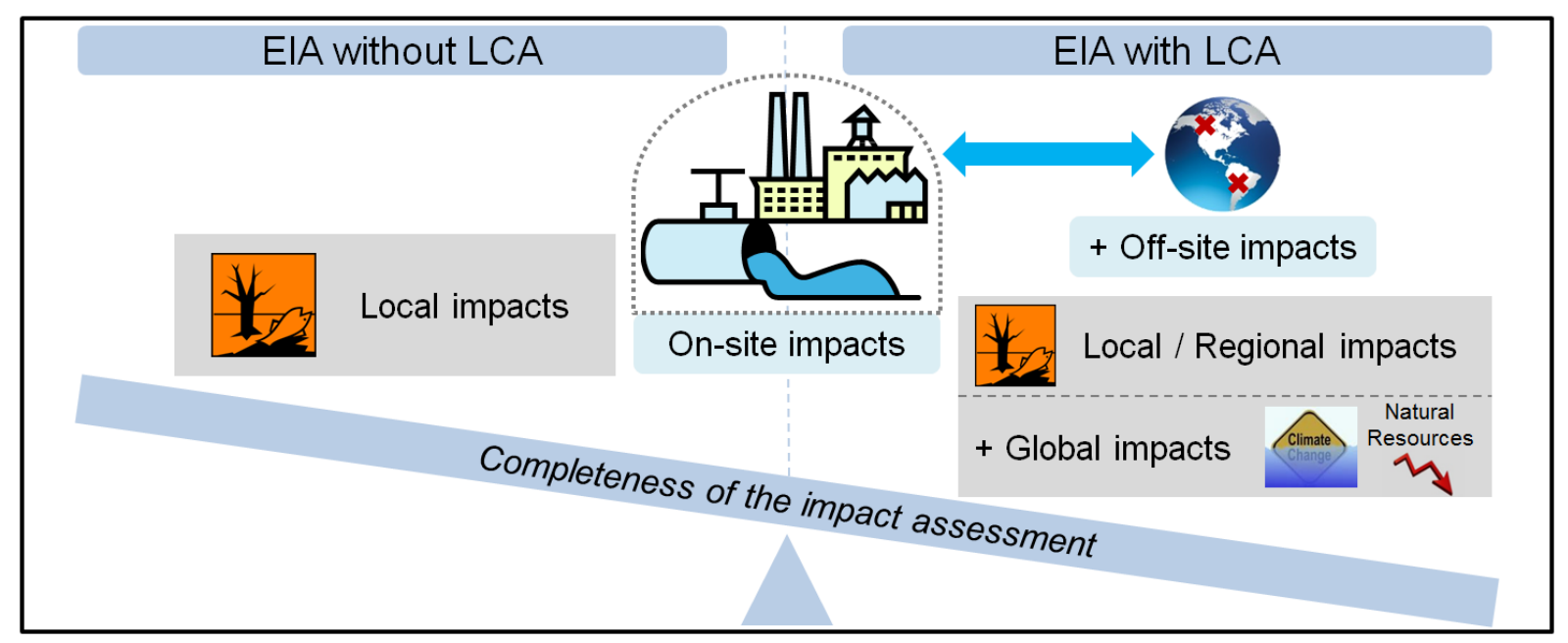

different conclusions. The environmental assessments of alternatives and mitigation measures were not carried out in the original studies and showed that other less polluting technologies could have been chosen. Regarding the scoping step, the selected environmental concerns were essentially different. Global impacts such as climate change or natural resource depletion were not taken into account in the original EIA studies. Impacts other than those occurring on the project site (off-site impacts) were not assessed, either. All these impacts can be significant compared to those initially considered. On the other hand, unlike current LCA applications, EIAs usually address natural and technological risks and neighbourhood disturbances such as noises or odours, which are very important for the public acceptability of projects. Regarding the impact assessment, even if the conclusions of the EIAs with or without LCA were partially common for local on-site impacts, LCA gives crucial additional information on global and off-site impacts and highlights the processes responsible for them. Finally, for all EIA steps investigated, interest in LCA was demonstrated for both WWTP case studies. The feasibility in terms of skills, time and cost of such implementation has also been assessed.

\section{Graphical abstract}

\section{Keywords}

Life Cycle Assessment (LCA); Integrated procedure; Wastewater Treatment Plant (WWTP); On-/Off-site impacts; Local/Global impacts 


\section{Introduction}

\subsection{Background}

Environmental Impact Assessment (EIA) is a widespread and legally required procedure used to support local decision-making. According to data collected by the European Commission, approximately 16,000 EIAs are conducted each year across the EU-27 for different types of projects, including infrastructure (i.e., energy, transport, waste and wastewater treatment) and industrial and urban development (GHK, 2010). EIA procedures vary in their details, but the practical stages in most systems are generally those illustrated in Figure 1. First, screening (step 1 in Figure 1) determines whether a proposal should be subject to an EIA. For example, European EIA directives apply to a wide range of defined public and private projects; some of them are always mandatory (e.g., long-distance railway lines or installations for the disposal of hazardous waste), whereas others are at the discretion of the member states based on a case-by-case examination or on thresholds set by the member state. Second, scoping (step 2-a in Figure 1) examines the project characteristics and establishes the preferred option for achieving the project's objectives (European Commission, 2001), for example, by choosing an alternative location or adopting a different technology or design for the project (Guidance on EIA - Scoping, 2001). The issues likely to be significant are then identified (step 2-b in Figure 1). In addition, scoping sets the scope and the temporal and geographical boundaries of the assessment. Third, the impact assessment phase, which is the core of the procedure, is generally divided into establishing an environmental baseline description before the project (current state) (step 3-a in Figure 1) and identifying, quantifying and evaluating the main environmental, social, and human health impacts (step 3-b in Figure 1) (IAIA and IEA, 1999). Fourth, mitigation measures are proposed to avoid, reduce, or offset the identified impacts (step 4 in Figure 1). Finally, a report is prepared, and after a review involving public opinion, the decision is made to approve or reject the project.

The EIA procedure relies on tools either for impact identification (scoping) or impact prediction (impact assessment). On the first point, different tools such as checklists, matrices, networks, consultations with local stakeholders (Ogola, 2007), map overlays, geographic information systems, expert systems, and professional judgement (UNEP, 2002) are usually used to ensure that all potential impacts are detected. For impact assessment, methods for predicting the characteristics of impacts include "best estimate" professional judgement, quantitative mathematical models, experiments, physical models, and case studies as analogues or points of references (UNEP, 2002). Therefore, EIA practitioners are free to use 
86 the best available methods or models and their own expertise to estimate project

87 environmental impacts (Ogola, 2007). Among these tools, several authors have suggested the use of analytical tools such as Life Cycle Assessment (LCA) (Bidstrup, 2015; Finnveden and Moberg, 2005; Jeswani et al., 2010; Manuilova et al., 2009; Potting et al., 2012; Tukker, 2000; Židonienè and Kruopienè, 2014). LCA is a standardised tool designed to assess environmental impacts throughout a product's life cycle, i.e., from raw material acquisition to waste management, via production and use phases (ISO, 2006a, 2006b). Although originally

93 focused on products and services, its application domain has recently expanded to LCAs of organisations, including specific sites (ISO, 2014). LCA assesses impacts with regard to functional units which reflect the quantified function(s) provided by the studied system. LCA has the double benefit of quantifying environmental impacts according to a life cycle hotspots and shifting burdens between impact categories and life cycle stages (Finnveden et al., 2009).

\subsection{Potential contributions of LCA to the EIA procedure: state of the art}

101 Based on a review presented hereafter, Figure 1 shows where LCA could bring valuable

102 contributions to some steps of the EIA procedure, i.e., during scoping (box-a and box-b), 103 impact assessment (box-c) and mitigation measures (box-d). 


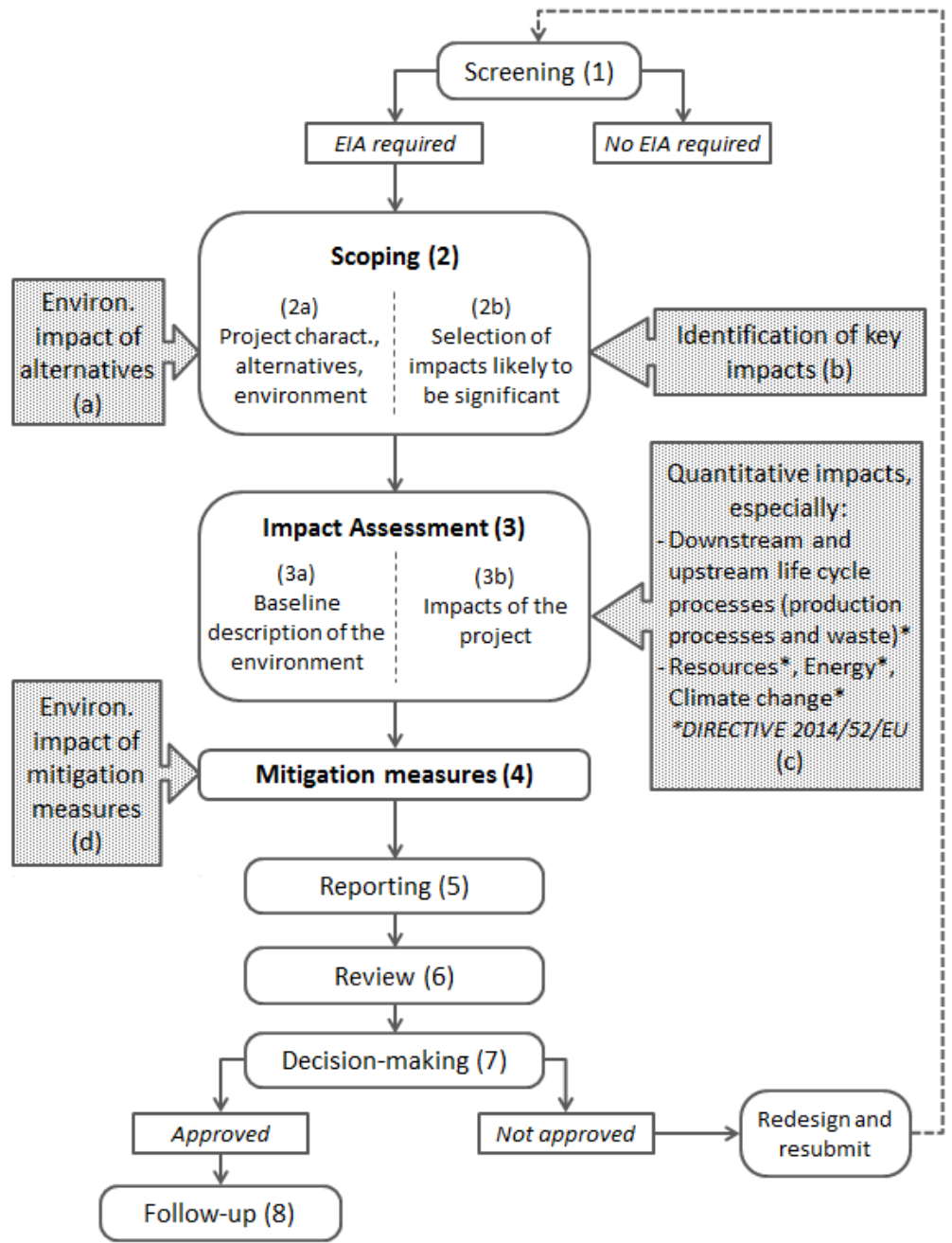

Figure 1: Potential contributions of the LCA approach (shown with arrows) to the EIA procedure

106 For the first scoping stage, Steinemann (2001) emphasised that the comparison of alternatives

107 should be based on explicit environmental factors. In this sense, Manuilova et al. (2009)

108 argued that LCA can be used to test all alternatives in depth (see box-a). Bidstrup (2015) also

109 stressed that the standardised LCA method can help EIAs be more explicit on their embedded

110 functions and provide a framework for the quantitative comparison of alternatives. At a higher

111 level than projects (i.e., plans, programmes and policies), a methodological framework for

112 Strategic Environmental Assessment (SEA) developed by Finnveden et al. (2003) also

113 suggested that LCA can be useful to support choices between different alternatives.

114 Moreover, Manuilova et al. (2009) suggested that LCA can be used to validate system

115 boundaries by considering both global and regional impacts throughout lifecycles. LCA could

116 add value to the scoping step when determining major issues that should be addressed as

117 priorities (arrowed box-b in Figure 1). 
118 For the impact assessment stage, as no specific or consensual analytical tool is imposed in

119 EIA, Life Cycle Impact Assessment (LCIA) methodologies could usefully provide complementary information (arrowed box-c in Figure 1). LCIA provides a life cycle impact-

121 oriented and quantitative assessment. In addition, with the development of site-dependent 122 LCIA methodologies, there is a high potential to apply these models to EIA to increase the 123 level of detail and accuracy of environmental assessment (Manuilova et al., 2009). Tukker 124 (2000) and Manuilova et al. (2009) put forward that LCA permits the inclusion of emissions 125 and effects related to upstream and downstream activities in the supply chain and not only at 126 the location of the process itself. The indirect impacts of projects can be extremely relevant, as they can be higher than the direct ones (Lenzen et al., 2003; Potting et al., 2012). This inclusion is strongly encouraged by recent European legislation (Official Journal of the 129 European Union, 2014). Regarding the nature of the impacts, Directive 2014/52/EU 130 emphasises the need to consider a wide range of impact categories that include "resource 131 depletion", "energy", "climate change" and "human health". The multicriteria approach 132 adopted by LCIA methods such as ReCiPe (Goedkoop et al., 2013) or ILCD (European 133 Commission et al., 2010a) is particularly adapted to this requirement.

134 Finally, LCA could have real added value for assessing the impacts of abatement alternatives 135 (Tukker, 2000) (arrowed box-d in Figure 1). So far, the impacts of mitigation measures and 136 their implementation have been rarely considered.

137 Still, even if several authors have argued that LCA is an appropriate analytical tool for 138 application in both EIA and SEA, little concrete application has yet been found in practice. A 139 review of 85 Danish EIA or SEA reports showed that $22 \%$ were supported by LCA results, 140 whereas only 7\% really applied LCA as part of the methodology (Bidstrup, 2015). To address 141 this issue, some recent publications have proposed formal yet partial procedures for such 142 integration.

143 Regarding preliminary applications for EIA, Tukker (2000) gave some examples of an actual 144 use of LCA in Dutch EIAs or SEAs and noted studies that could have benefited from LCA, 145 essentially to provide a quantitative assessment of process alternatives but also to compare 146 different abatement alternatives. Cornejo et al. (2002) proposed to use LCA in EIA and 147 applied it to a major modernisation project of a newsprint mill. After assessing the 148 environmental impacts of the project alternatives, they compared concentrations of significant 149 air, water and solid waste emissions with environmental regulations. Židoniene and 150 Kruopienè (2014) recently proposed an integrated LCA-EIA framework to compare several 
151 alternatives for a project. They compared different material insulation production scenarios

152 with LCA to identify the one with the lowest environmental impacts. In line with Cornejo et 153 al. (2002), they then proposed to assess the compatibility of the selected scenario with local 154 conditions, i.e., air emissions, water pollution and site location with regard to biodiversity, 155 protected areas and social environment. Morero et al. (2015) offered a comparison of the 156 impact assessment of biogas upgrading processes, with LCA on one hand and with a specific 157 cause and effect matrix used to comply with Argentinian EIA legislation on the other hand.

158 Regarding preliminary applications for SEA, Björklund (2012) used LCA in combination 159 with other planning tools to design the scope of the environmental assessment and defining 160 and assessing alternatives for municipal energy planning in Sweden. Bidstrup et al. (2015) proposed an LCA procedure for operationalising LCA in SEA. They defined several scenarios for Danish extraction planning and compared them on the basis of the two most significant impact categories of the baseline scenario.

\subsection{Aim of the paper}

165 First, this paper aims to propose an advanced integration of LCA within the EIA procedure.

166 Many authors have discussed the analytical benefits of applying LCA in EIA in theory, and 167 some of them already proposed preliminary procedures for a partial integration of LCA in 168 some specific steps of the EIA procedure. Most mainly focused on assessing project alternatives with LCA and then discussing LCA results in the context of a specific location.

170 The proposed procedure differs from prior studies by its effort in considering not only 171 alternatives assessment but also other EIA steps. We offer to put all potential LCA analytical 172 gains noted in the literature into practice in a comprehensive procedure. Concretely, we first 173 clarified which steps of the standardised EIA procedure could benefit from LCA and then 174 provided a complete methodology for an exhaustive LCA integration in EIA.

175 Second, the purpose of this study is to test ex-post the implementation of this innovative procedure in real EIA case studies (first-stage implementation) to further investigate the interest and feasibility of using LCA in an EIA procedure. For this purpose, we compare the outputs from an existing EIA procedure without LCA with the outputs from an EIA procedure using LCA as an analytical tool. We want to see if the main conclusions differ, and if so, how and to what extent LCA could actually contribute to EIA. This comparison is conducted using

181 two real case studies dealing with wastewater treatment plants. This first-stage 182 implementation can be seen as a proof of concept for analysing the LCA inputs within the 
183 EIA procedure. Nevertheless, this first step does not substitute to an effective and practical

184 implementation of the proposed approach in real time during an EIA process including 185 interactions with regulation authorities as well as a feedback analysis on decision-making 186 (which is out of the scope of this paper).

187 Thus, the two main original aspects of our work are a comprehensive integration of LCA in the EIA procedure and the demonstration of LCA benefits based on existing case studies.

\section{Materials and methods}

\subsection{Integration of inputs from LCA into four EIA procedure steps}

191 The proposed methodology consists of revisiting an existing EIA (conducted ex-ante) by

192 introducing LCA at different steps (conducted ex-post). It aims to demonstrate the added

193 value and feasibility of including LCA in the EIA procedure in future studies. The final 194 objective of the methodology is to apply LCA throughout an actual EIA study, both 195 conducted simultaneously.

196 For the sake of demonstration, the LCA was conducted at each step of the EIA procedure as if 197 both studies were carried out at the same time. For example, during step (2-a), LCA was used 198 to compare the alternative scenarios based on standard Wastewater Treatment Plant (WWTP) 199 technologies because at that point the system to be chosen and the precise future design of the 200 processes are unknown. However, during step (3-b), the actual data for the design were 201 assumed to be available, and the impacts of the technologies were assessed with LCA based 202 on the actual data. LCA was therefore implemented at each relevant EIA step with a specific 203 goal and scope. In addition, different indicators are provided, as presented in Table 1. 204 Endpoint indicators are used for comparison or for environmental issues identification. 205 Midpoint indicators are used for eco-design and the identification of hotspots that need to be 206 mitigated.

Table 1: Specific LCA analysis used at each of the four selected EIA steps

\begin{tabular}{|l|l|l|l|}
\hline $\begin{array}{l}\text { Step of the EIA } \\
\text { procedure }\end{array}$ & Aim of the LCA & $\begin{array}{l}\text { Object of the } \\
\text { LCA study }\end{array}$ & $\begin{array}{l}\text { LCA analysis and associated } \\
\text { indicators }\end{array}$ \\
\hline $\begin{array}{l}\text { Step 2-a: } \\
\text { Alternatives }\end{array}$ & $\begin{array}{l}\text { Comparison of } \\
\text { alternatives and } \\
\text { identification of best } \\
\text { option }\end{array}$ & $\begin{array}{l}\text { LCA of all } \\
\text { potential } \\
\text { alternatives }\end{array}$ & Analysis at endpoint level \\
\hline
\end{tabular}




\begin{tabular}{|c|c|c|c|}
\hline $\begin{array}{l}\text { Step 2-b: } \\
\text { Scoping }\end{array}$ & $\begin{array}{l}\text { Identification of main } \\
\text { environmental } \\
\text { concerns (hotspots) }\end{array}$ & \multirow[b]{2}{*}{$\begin{array}{l}\text { LCA of } \\
\text { selected } \\
\text { alternative }\end{array}$} & $\begin{array}{l}\text { Analysis at endpoint level, including } \\
\text { the contribution of each midpoint } \\
\text { impact to each endpoint category. } \\
\text { Nota bene: The few midpoint } \\
\text { indicators that are not developed at } \\
\text { the endpoint level are considered by } \\
\text { default as environmental concerns. }\end{array}$ \\
\hline $\begin{array}{l}\text { Step 3-b: Impact } \\
\text { Assessment }\end{array}$ & $\begin{array}{l}\text { Identification of main } \\
\text { contributing life-cycle } \\
\text { stages with: } \\
\text { - a differentiation } \\
\text { between on-site and } \\
\text { off-site impacts } \\
\text { - a differentiation } \\
\text { between local/regional } \\
\text { and global impacts }\end{array}$ & & $\begin{array}{l}\text { Analysis at midpoint and endpoint } \\
\text { levels }\end{array}$ \\
\hline $\begin{array}{l}\text { Step 4: } \\
\text { Mitigation } \\
\text { measures }\end{array}$ & $\begin{array}{l}\text { Contribution of the } \\
\text { impacts of the } \\
\text { implementation of } \\
\text { mitigation measures to } \\
\text { the entire WWTP } \\
\text { impacts }\end{array}$ & $\begin{array}{l}\text { LCA of } \\
\text { mitigation } \\
\text { measures }\end{array}$ & $\begin{array}{l}\text { Analysis at midpoint and endpoint } \\
\text { levels }\end{array}$ \\
\hline
\end{tabular}

The results of the LCA approach are then compared with the conclusions of existing current analytical methods or expert judgement mobilised in the EIA for each of those steps. Finally,

210 the possible contribution of LCA to EIA is assessed by analysing whether the LCA 211 integration changes the overall conclusions of the EIA study. The practical feasibility of the methodology in terms of means, resources and costs is discussed.

\section{$213 \quad 2.2 \quad$ Application to two case studies}

$214 \quad 2.2 .1$ Choice and description of the case studies

215 The choice of case studies is based on three criteria, i.e., i) availability of existing EIA reports,

216 (ii) availability of emission and resource use data and iii) opportunities to identify different 217 alternatives to the proposed project. In addition, infrastructure projects, including water 218 management, represent a large part of European EIA studies (GHK, 2010), and WWTPs are 219 great contributors of water management EIAs. We thus have decided to focus on the 220 environmental impact assessment of WWTPs in France. This choice is appropriate given that many wastewater treatment projects have recently been conducted in Europe to meet the requirements of the EU Water Framework Directive. WWTPs generate impacts on local water 
due to protected areas. Both case studies and the main results of the EIA procedures are summarised in Table S 1, Table S 2 and Table S 3 based on technical documents produced during the procedures. Only information regarding the four EIA steps where LCA could provide interesting information (Boxes a, b, c, and d in Figure 1) are described in these tables. Both case studies are located in small cities in eastern France and have similar characteristics, except for the presence of a Natura 2000 area (EU protected nature conservation areas, including terrestrial and marine sites).

231 In many cases, the impacts are not addressed in the same section of the report, either because 232 they come from different sources or because they do not have the same targets. For example, 233 EIA differentiates between the "receiving environment" (surface water) and the "site" (other 234 targets) or sanitary impacts. Consequently, the comparison with LCA-which produces results by impact category (e.g., climate change or eutrophication) - is not straightforward. To allow an easier and consistent comparison with LCA, the raw data have been re-classified (see Table S 4 for details on the reorganisation) to gather the same issues and extract concise and relevant indications in the Results section.

239 As the report is mainly descriptive and qualitative, we also propose to weight the impacts 240 from minor concern (0 - no potential impact identified in the EIA) to moderate concern (1 impact, but no proposed mitigation measures) and major concern (2 - impact, with proposed mitigation measures) depending on the qualitative content of each paragraph and whether corrective or mitigation measures are planned.

\subsubsection{LCA of the two case studies}

This section presents the implemented assessments following the four stages of LCA methodology as defined by ISO 14044 (ISO, 2006b).

\section{LCA goal and scope}

248 For the two case studies, several WWTP alternatives are considered in the respective EIA 249 studies (Table S 1). Infiltration-Percolation (IP) has not been assessed by LCA because vertical Reed Bed Filters (vRBF) are always preferable, as they have fewer operating constraints (M.A.G.E. 42, 2007). Regarding intensive technologies, even if Activated Sludge (AS) and Activated Sludge Sequencing Batch Reactors (AS-SBR) have significant differences regarding treatment chronology, they have been assimilated to similar technologies as a proxy

254 (the infrastructure construction and energy consumption are quite alike). Finally, because no 255 Life Cycle Inventory (LCI) data are available for Biological Disks (BD) and because this 
technology is not widespread in France-only $2.2 \%$ of the WWTP < 2000 population 257 equivalent (p.e.) in 2008 (Golla et al., 2010) - BD have not been modelled in this study. The 258 WWTPs alternatives assessed by LCA are summarised in Table 2.

\section{Case study 1}

Choice, design and impact assessment of a new WWTP for the municipality of Altwiller

\section{Case study 2}

Choice, design and impact assessment of a new WWTP for the municipalities of Niedersteinbach and Obersteinbach study

Treatment of wastewater load from one population-equivalent (p.e.) during one

LCA Functional unit (FU) day $\left(1\right.$ p.e. $=60 \mathrm{gBOD}_{5} /$ day $)$

From all WWTP life-cycle stages to freshwater ecosystem, including WWTP System boundaries construction, operation and maintenance, final dismantling and sludge end-of-life (Risch et al., 2015). The sewer system is not modelled for both case studies because it is identical for all alternatives. The mitigation measures planned during the EIA are also considered.

Population Equivalent (p.e.)

WWTP assessed AS, AS-SBR, vRBF (respectively, by LCA

denoted AS1, AS-SBR1, and vRBF1)
AL, NL, AS, AS-SBR, hRBF, vRBF (respectively, denoted AL2, NL2, AS2, AS-SBR2, hRBF2, and vRBF2)

$A S=$ Activated Sludge and AS-SBR=Activated Sludge Sequencing Batch Reactor $/ v R B F=$ vertical Reed Bed Filters $/$ $h R B F=$ horizontal Reed Bed Filters $/ N L=$ Naturally Aerated Lagoons $/ A L=$ Artificially Aerated Lagoons

Life Cycle Inventory

261 Different WWTP models were used, and the data sources for the LCI of each technology are 262 provided in Table S 5. For all the WWTP models, agricultural spreading was considered to be 263 sludge end-of-life, which is the case in both case studies. Emissions to water and air were estimated for phosphorus, nitrogen, carbon compounds and micropollutants (Choubert et al., 2011). For all these substances, the influent composition is compared to emissions and sludge compositions to comply with the mass balance. A selected inventory for the modelled

267 WWTPs is described in the supporting information (Table $S$ 6). The data presented correspond to the major operational parameters of a WWTP, the main infrastructure information, and conventional emissions to air and water. A distinction was made in the LCIs between the foreground and background activities to enable comparison with the EIA results. 
to on-site discharge and land occupation during the operational phase of the WWTP, whereas

273 background activities correspond to the off-site activities needed for the construction phase 274 (production and transport of all materials and equipment), the off-site activities needed for the operational phase of the WWTP (e.g., electricity production) and the sludge end-of-life. The

276 Ecoinvent database version 3.1 was used for all background data. Regarding the impacts of 277 the implementation of mitigation measures, a description of the associated LCIs is provided in 278 Table S 7. These inventories involve coarse assumptions about civil engineering works 279 because the goal here is not to obtain accurate results but rather the orders of magnitude of the 280 potential impacts associated with such measures.

\section{Life Cycle Impact Assessment}

282 For the impact calculation phase, both the ReCiPe Midpoint and ReCiPe Endpoint version 2831.112010 methods (Goedkoop et al., 2013) are used. The ReCiPe method calculates eighteen midpoint indicators (i.e., between environmental interventions and damages in the cause and effect chain) and three endpoint indicators (i.e., at the end of the cause and effect chain, indicating damages to human health, ecosystems and resource availability). The motivation to use endpoint indicators is the large number of midpoint indicators and their partially abstract meaning. Thus, damage modelling aids in the understanding and interpretation of midpoint indicators by making results in different midpoint categories cross-comparable within Areas of Protection (European Commission et al., 2010b).

\section{LCA interpretation}

292 LCA is implemented at each relevant EIA step with a specific goal and scope and associated 293 set of indicators (Table 1). To facilitate the interpretation of the scoping and mitigation 294 measures (EIA - steps 2 and 4), all the results are presented as a whole, without 295 distinguishing on-site/off-site impacts or local/global impacts. However, for the interpretation of the results relative to the impact assessment step (EIA - step 3-b), we propose a further refinement. We differentiate between on-site impacts (impacts due to emissions occurring on the site of the project) and off-site impacts (impacts due to emissions occurring outside of the site, e.g., manufacturing plants in other parts of the globe). Regarding the environmental mechanisms, in LCA they are usually classified - in a rather simplistic way-according to their "spatial scale". Global environmental mechanisms such as climate change, ozone

302 depletion and fossil fuel/mineral resources depletion will have the same potential impact wherever the emissions/consumptions occur on the planet. This does not mean that the effects

304 (i.e., the consequences of climate change on human health and ecosystems) will not vary 
locally. In contrast, for non-global mechanisms (referred to as local or regional), the geographical situation of an emission or resource consumption has an influence on the magnitude of its impact. Environmental mechanisms such as acidification, eutrophication, photochemical oxidant formation, (eco)toxicity, land use and water use depend on regional conditions (Goedkoop et al., 2013). Figure 2 illustrates the possible differentiations; some impacts can be local and on-site (e.g., eutrophication in the river next to the site), global and on-site (e.g., climate change due to WWTP discharges), local and off-site (e.g., ionizing radiations at nuclear power plant), global and off-site (e.g., resource depletion associated with energy production).

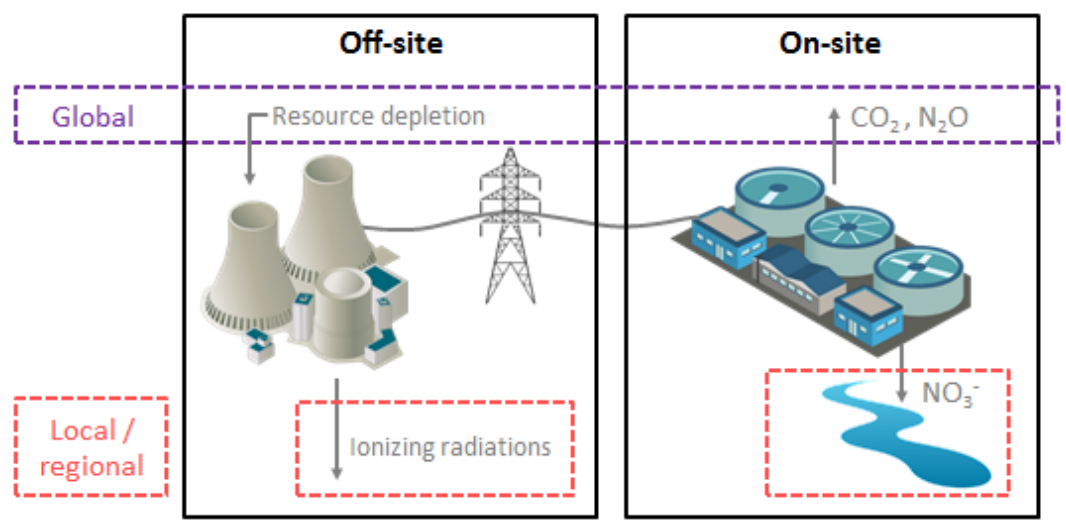

Figure 2: Differentiation between on/off-site activities and global/regional/local environmental mechanisms

316 The contributions of the different wastewater treatment life cycle stages are also examined in 317 the EIA impact assessment step.

\section{Results}

\subsection{Previous EIA conclusions (without inputs from LCA)}

320 For step 2-a, the alternatives were chosen based on technical criteria and local pressures (see 321 Table S 1). For case study 1, reed bed filters were selected, whereas the activated sludge process was preferred for case study 2. For step 2-b, EIA established spatial and temporal boundaries, but the selection of environmental concerns was mainly implicit and based on consultants' expertise and the regulatory constraints on this type of project. For step 3-b,

325 Table S 8 qualifies the different issues according to the evaluation levels 0 (minor) to 2

326 (major) described previously. Impacts due to extreme climatic events were not considered.

327 The identified issues of major concern for both case studies are the impact of land 328 transformation occurring during construction and water pollution during the operation of the 
329 WWTP. Change in water flows is also a major issue for case study 1 and landscape alteration

330 for case study 2. Other issues of less importance are noise during construction for both case 331 studies and odours during the operation phase of the WWTP for case study 1. Finally, 332 although mitigation measures were integrated in the project (step 4), their impacts were not 333 considered in either EIA report.

\section{$334 \quad 3.2 \quad$ LCA results (ex-post) for the four EIA steps}

\section{3.2.1 LCA results for EIA Step 2-a: Alternatives}

336 Case study 1: Considering the endpoint indicators (Figure S 1), vertical reed bed filters are 337 more efficient from an environmental perspective than the activated sludge process for all 338 three areas of protection (human health, ecosystems and resources). This trend can be 339 explained by the smaller impact of reed bed filters compared to activated sludge for all 340 midpoint categories (Figure S 2), except for eutrophication (freshwater and marine) and 341 occupation of urban area. This is due to (i) the less effective treatment of nitrogen and 342 phosphorus by reed bed filters and (ii) their higher area requirements (extensive processes 343 need more area per capita).

344 Case study 2: In view of the endpoint indicators (Figure 3), the naturally aerated lagoon 345 system is clearly the worst performing alternative for human health and ecosystems and has 346 the second greatest impact on resource depletion. This result is because the only midpoint 347 indicators in which this lagoon system is the worst alternative are those that contribute most to 348 the endpoint indicators (Figure S 3). The values of the potential impacts generated by the activated sludge process are intermediate, and the best apparent alternatives are vertical reed bed filters and artificially aerated lagoons. 


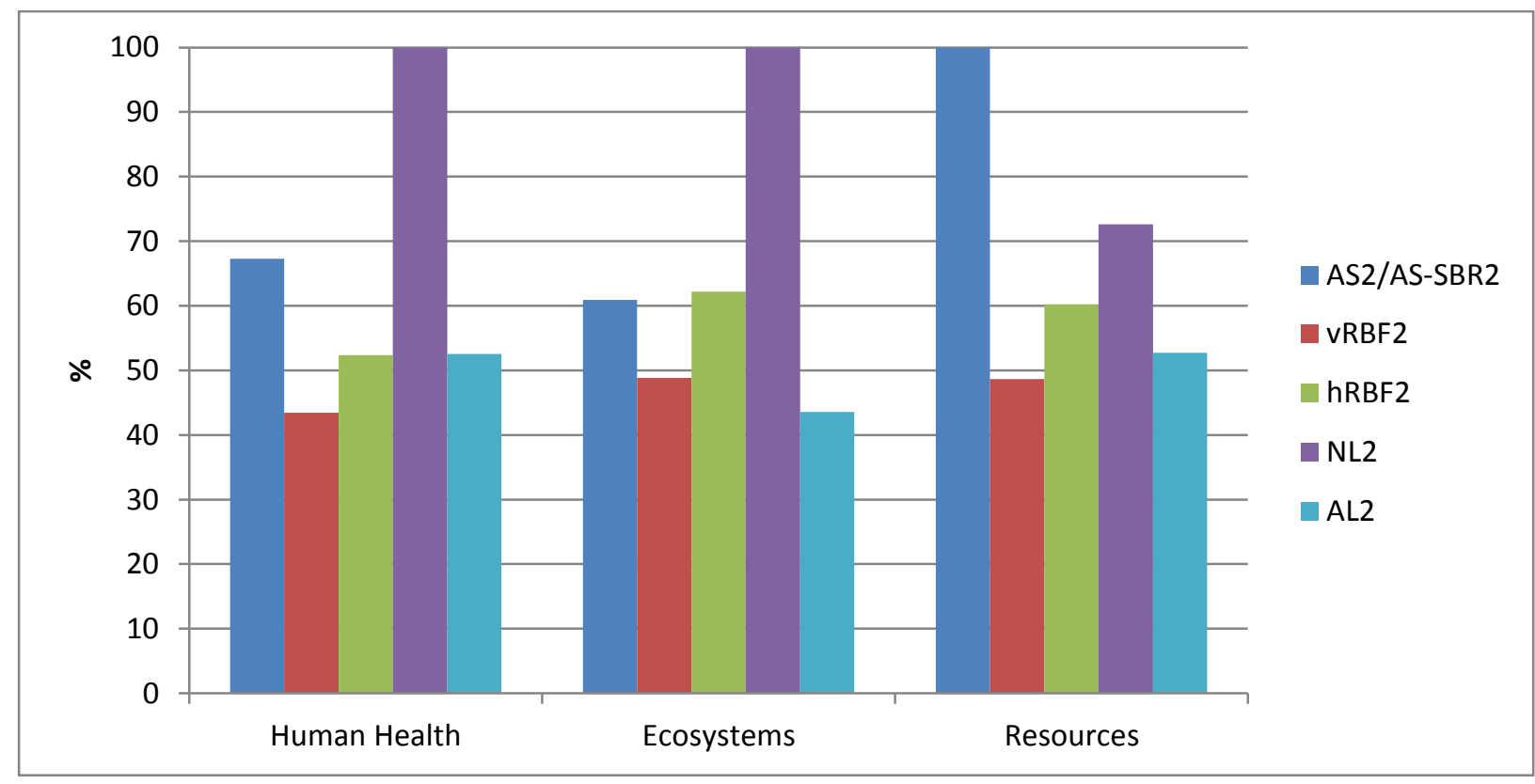

Figure 3: Endpoint impacts of the theoretical alternatives for case study 2

\subsubsection{LCA results for EIA Step 2-b: Identification of key impacts}

354 To judge the weight of the environmental concerns in the total impact of the WWTP, the 355 contribution of each midpoint indicator to the three endpoint indicators (human health, 356 ecosystems and resources) is considered. Table 3 summarises the main environmental 357 concerns identified in the LCA results. The percentages indicate the contribution of the 358 midpoint indicator to the endpoint indicator, respectively, for case studies 1 and 2. LCA 359 expands the conventional EIA system boundaries to the entire Life Cycle of the WWTP. This 360 allows for accounting and analysing a broader set of impacts (in particular global impacts), 361 which is of great interest for the scoping step.

Table 3: Scoping with the LCA method (for both case studies)

\begin{tabular}{|c|c|c|c|}
\hline & $\begin{array}{c}\text { Human health } \\
\text { (Figure } S \\
\text { 4Erreur ! Source } \\
\text { du renvoi } \\
\text { introuvable.) }\end{array}$ & $\begin{array}{l}\text { Ecosystems } \\
\text { (Figure S 5) }\end{array}$ & $\begin{array}{l}\text { Resources } \\
\text { (Figure S 6) }\end{array}$ \\
\hline $\begin{array}{l}\text { Main contributor(s) to } \\
\text { endpoint indicators }\end{array}$ & $\begin{array}{l}\text { Climate change } \\
(86 \% \text { and } 82 \%)\end{array}$ & $\begin{array}{l}\text { Climate change } \\
(64 \% \text { and } 90 \%)\end{array}$ & $\begin{array}{l}\text { Fossil depletion } \\
(89 \% \text { and } 85 \%)\end{array}$ \\
\hline $\begin{array}{l}\text { Secondary contributor(s) to } \\
\text { endpoint indicators }\end{array}$ & $\begin{array}{l}\text { Human toxicity } \\
\text { (7\% and 10\%) } \\
\text { Particulate matter } \\
\text { formation } \\
\text { (both } 7 \% \text { ) }\end{array}$ & $\begin{array}{l}\text { Urban land occupation } \\
\qquad(34 \% \text { and } 4 \%) \\
\text { Freshwater eutrophication } \\
\text { (both 3\%) }\end{array}$ & $\begin{array}{l}\text { Metal depletion } \\
(11 \% \text { and } 15 \%)\end{array}$ \\
\hline
\end{tabular}




\begin{tabular}{|c|c|c|c|}
\hline $\begin{array}{c}\text { Midpoint indicators not } \\
\text { developed at the endpoint } \\
\text { level }\end{array}$ & - & Marine eutrophication & \\
\hline
\end{tabular}

363

364

However, one should be aware that data gaps influence the conclusions that can be drawn. For example, only 15 micropollutant substances could be assessed, either because they were not measured in the WWTP or because they were not characterised by the impact method used in the study. Therefore, the impacts on human toxicity and ecotoxicity may be underestimated and even eliminated during the scoping step (as for ecotoxicity), although they are relevant.

\subsubsection{LCA results for EIA Step 3-b: Impact assessment}

The aim of the impact assessment is to assess the contribution of the different WWTP lifecycle stages to highlight the sources of impacts previously identified during scoping. The contribution analysis was carried out on midpoint indicators. Based on the previous scoping phase, we restricted the scope of the study to the nine main contributing midpoint indicators.

Case study 1: Regarding the three global issues (climate change, fossil depletion and metal depletion), most of the climate change impact is due to the direct atmospheric emissions occurring during the operation step of the WWTP (operation on-site, mainly $\mathrm{CO}_{2}, \mathrm{~N}_{2} \mathrm{O}$ and $\mathrm{CH}_{4}$ emissions), whereas the depletion of fossil and metal resources is due to background activities (Figure 4). In particular, off-site construction (i.e., production and transport of all materials and equipment needed for the infrastructure) is the main contributor to metal and fossil depletion. The contribution to global impacts of off-site WWTP operation activities (e.g., energy production, production and transport of reagents, and transport operations for maintenance) is not negligible, whereas the sludge end-of-life has generally little impact (less than $5 \%$ ).

For the six regional/local issues, four impacts are essentially due to foreground activities; eutrophication (freshwater and marine) and human toxicity are mainly dominated by the direct emissions of the WWTP (operation on-site), and urban land occupation is directly related to the area requirement of the WWTP (operation on-site). The remaining regional/local issues (particulate matter formation and water depletion) can essentially be associated with background activities. Sludge end-of-life still has a minor impact. 


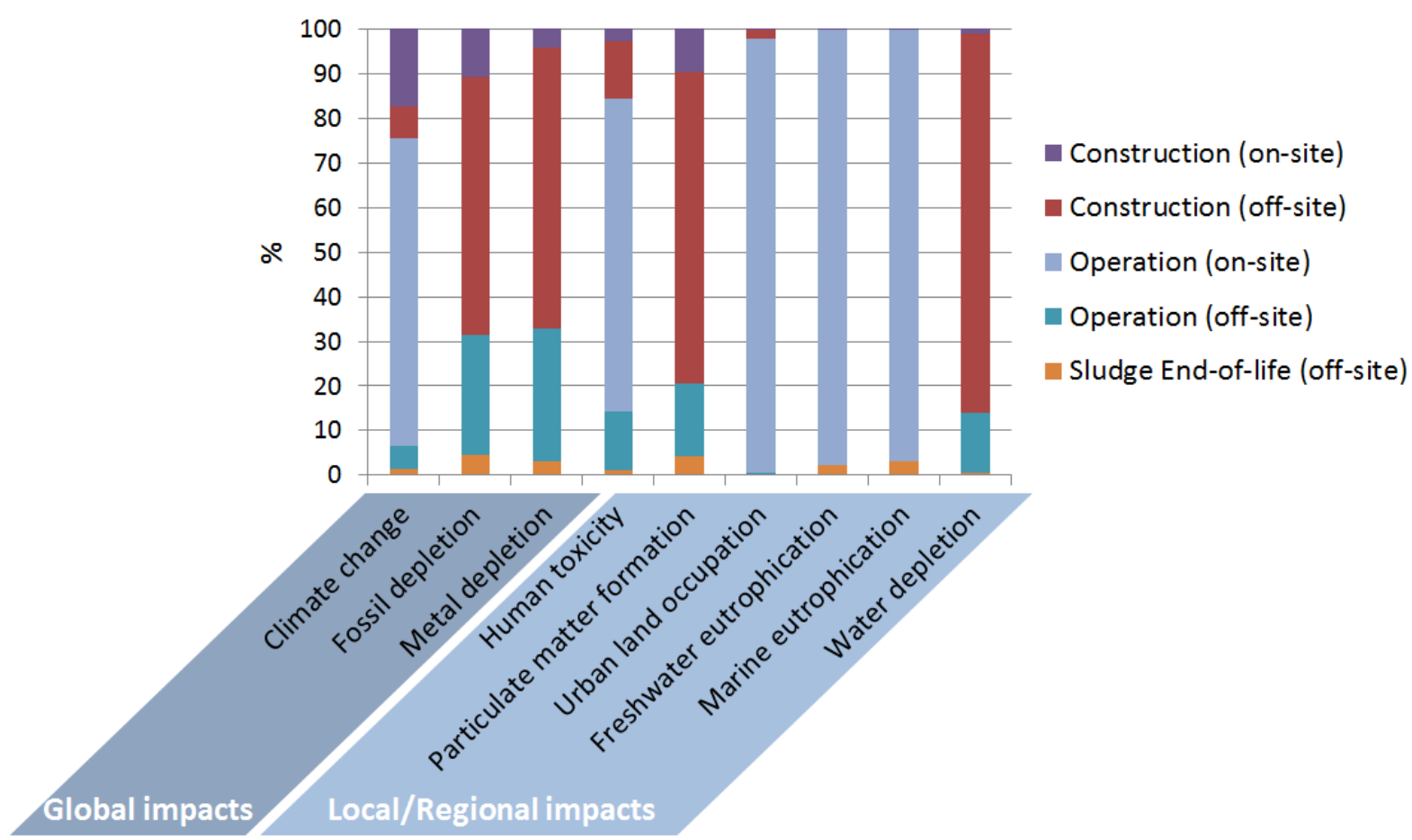

391 Case study 2: Regarding global issues, most of the climate change impact is due to on-site activities (Figure 5). As in case study 1, this is due to the on-site atmospheric emissions of the WWTP, but in this case the contribution of emissions linked to diesel combustion during construction is higher. Here, too, fossil and metal depletions are due to background activities. The sludge end-of-life contributions are low but higher than in case study 1 (almost up to $10 \%)$.

397 For regional/local issues, the conclusions are also similar to case study 1; the same four 398 impacts are essentially due to the same foreground activities: eutrophication (freshwater and marine), human toxicity and urban land occupation. However, marine eutrophication is almost equally distributed between the foreground and background activities. Particulate matter formation and water depletion are also mainly associated with background activities. Here, too, the sludge end-of-life has generally little impact, except for marine eutrophication (responsible for $40 \%$ of the impacts).

404 As for case study 1, half of the impacts are associated with foreground activities (construction 405 or on-site operation activities), whereas the others represent mainly off-site impacts due to 406 background activities of the WWTP (Figure 5). However, contrary to case study 1, for case 407 study 2, the off-site impacts are mainly due to background operation activities and, to a lesser 408 extent, infrastructure. Indeed, off-site construction is the main contributor for 1 indicator only 
(metal depletion), versus 4 for case study 1, and off-site impacts of the WWTP operation are the largest contributors to 3 indicators, versus none for case study 1.

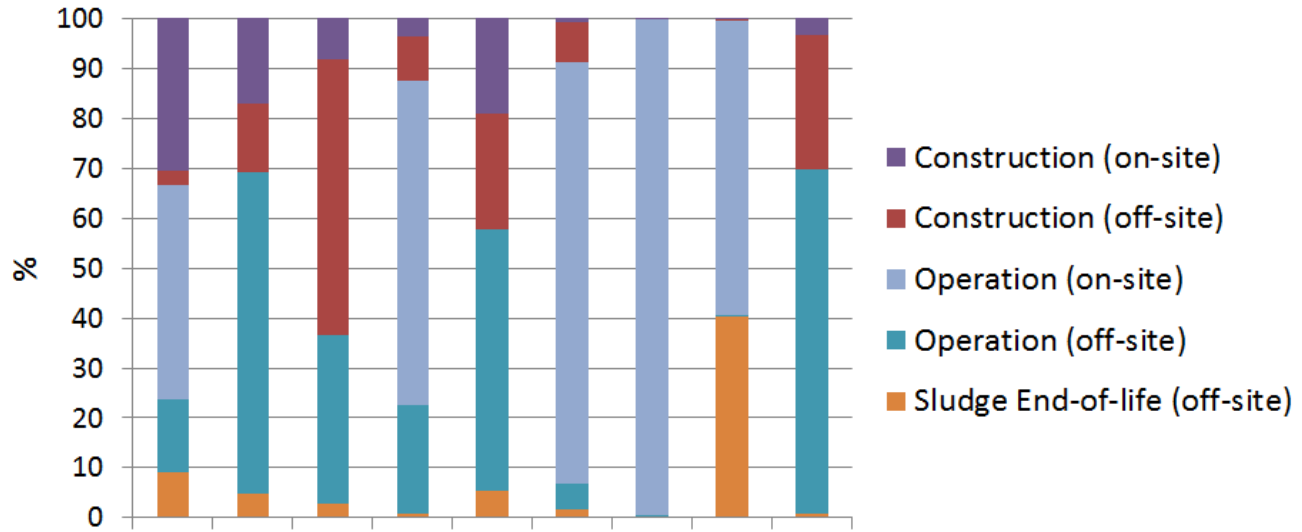

Figure 5: Selected midpoint impacts of real case study 2

413 The contribution analysis also allows an explanation of the observed differences in Figure $S$ 4145 ; compared to case study 1 , the contribution of climate change to ecosystem damage is 415 higher in case study 2, essentially because of electricity consumption during the operation 416 phase of the WWTP but also because of the use of polymers. On the other hand, the 417 contribution of urban land occupation is lower because of the compactness of the activated 418 sludge process compared to reed bed filters, which require larger land areas.

419 From the scoping, we learned that for both case studies the main contributor to both human 420 health and ecosystems endpoint indicators is climate change. This is essentially due to 421 foreground activities, mainly to on-site atmospheric emissions during WWTP operation $422(69 \%)$ for case study 1 and construction (30\%) and on-site atmospheric emissions during 423 WWTP operation (43\%) for case study 2 (first bars in Figure 4 and Figure 5). Background 424 processes via off-site construction, off-site operation and sludge end-of-life for case study 1, 425 and mainly off-site operation for case study 2 also have a significant role in climate change. 426 Note that for other business sectors such as tertiary activities requiring electricity generated 427 from fossil fuels, background activities can be responsible for a large part of the climate 428 change impact. 
The impacts of case study 1 (Figure 6) are mainly global, and they are more likely to occur on-site. The case study 2 results are similar to the case study 1 results (Figure S 7), except that the off-site impacts are slightly more important for human health and ecosystems and damages to resources tend to more frequently occur on-site than for case study 1 . The

433 local/regional impacts on ecosystems are higher for case study 1 than for case study 2 ; in this 434 case, they are essentially global (climate change).

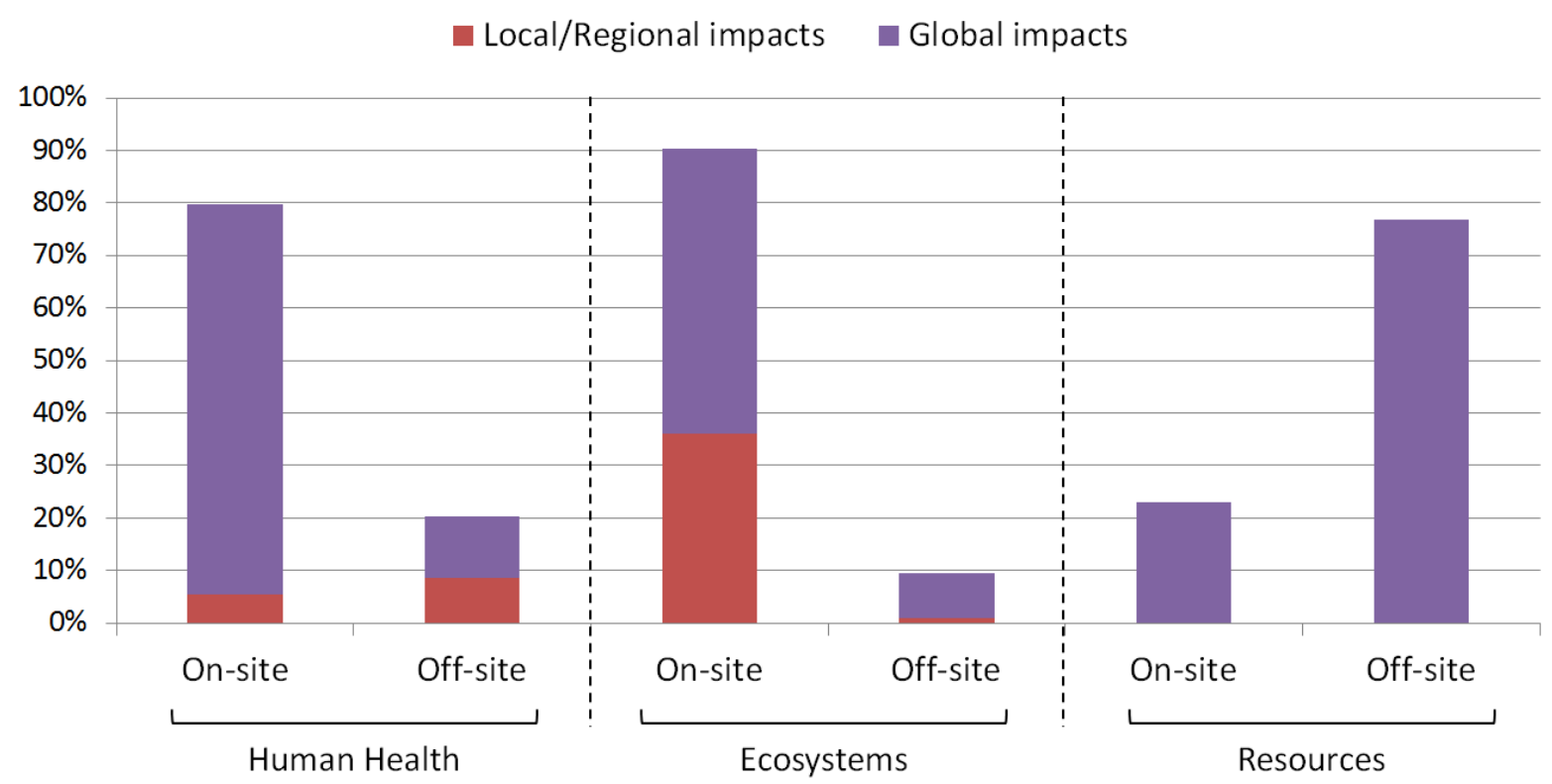

Figure 6: Main concerns exposed based on LCA endpoint indicators for case study 1

437 Based on these conclusions, other mitigation measures than those implemented in EIA case studies without LCA could have been proposed. To decrease global impacts, the focus should 439 be on monitoring on-site atmospheric emissions and optimising water flows for case study 1 440 (vRBF) or basin aeration conditions for case study 2 (AS) to avoid emissions of 441 nitrification/denitrification by-products (e.g., $\mathrm{N}_{2} \mathrm{O}$ ). A system for collecting greenhouse gases 442 could also be implemented. Other materials for infrastructure could be preferred when 443 possible. Locally produced, renewable energy may be a good option to reduce impacts due to 444 electricity consumption. Transport itineraries for materials, maintenance or sludge end-of-life 445 could perhaps be optimised, and diesel vehicles could be replaced by less polluting vehicles. 446 To decrease local/regional impacts, the possible mitigation measures would mainly be on-site; 447 there must be additional efforts to decrease local discharges, even if they already are in line 448 with regulations. Land occupation should also be mitigated. 


\subsubsection{LCA results for EIA Step 4: Mitigation measures}

450 The impacts of the implementation of the mitigation measures have been assessed for case study 1 , and their contribution to the entire WWTP impacts has been calculated (Figure S 8 and Figure S 9). For case study 2, fewer mitigation measures were set up, and they were not significant enough to modify the inventory, e.g., the required amounts of materials and the transport distances (see Table S 7). In the case of a very extensive technology with few civil engineering works such as reed bed filters, the impacts of the implementation of the mitigation measures turn out to be significant. They range from less than $1 \%$ (e.g., eutrophication) to $58.2 \%$ (terrestrial ecotoxicity) for midpoint indicators and from $14.4 \%$ (resources) to $20.4 \%$ (human health) for endpoints indicators. The same implementation of mitigation measures on activated sludge would be smaller; for example, for terrestrial ecotoxicity, the impacts of implementation of mitigation measures would only represent $6.8 \%$ of the WWTP impacts.

462 Note that if LCA can be used to assess the impacts of the implementation of the mitigation 463 measures, the final effectiveness of the mitigation measures was not evaluated by LCA 464 because it only assesses potential impacts, not predictions.

\section{$4654 \underline{\text { Discussion }}$}

\section{4.1 Do the EIAs conclusions with or without LCA differ?}

467 The possible contribution of LCA to EIA is assessed by analysing whether or not the LCA 468 implementation changed the overall conclusions of the EIA study (Table 4). The results show that the EIAs conclusions with or without inputs from LCA strongly differ.

Table 4: Difference for the EIAs conclusions with or without LCA implementation

\begin{tabular}{|c|c|c|c|c|}
\hline & \multicolumn{2}{|c|}{ Case study 1: EIA conclusions } & \multicolumn{2}{|c|}{ Case study 2: EIA conclusions } \\
\hline & Without LCA & With LCA & Without LCA & With LCA \\
\hline \multirow[b]{2}{*}{$\begin{array}{c}\text { Step 2-a: } \\
\text { Alternatives } \\
\text { and choice of } \\
\text { a solution }\end{array}$} & \multicolumn{2}{|c|}{ Same preferred option: reed bed filters } & \multicolumn{2}{|c|}{ Different conclusions } \\
\hline & $\begin{array}{l}\text { Conclusion } \\
\text { driven by } \\
\text { technical } \\
\text { criteria }\end{array}$ & $\begin{array}{l}\text { Conclusion driven by } \\
\text { environmental profile }\end{array}$ & $\begin{array}{l}\text { Preferred option = } \\
\text { activated sludge } \\
\text { (based only on } \\
\text { local pressure on } \\
\text { land) }\end{array}$ & $\begin{array}{c}\text { Preferred options }=\text { reed } \\
\text { bed filters and aerated } \\
\text { lagoons (environmental } \\
\text { profiles) }\end{array}$ \\
\hline Step 2-b: & \multicolumn{2}{|c|}{ Different scope and hotspot analysis } & \multicolumn{2}{|c|}{ Different scope and hotspot analysis } \\
\hline
\end{tabular}


Author-produced version of the article published in Environmental Impact Assessment Review, 2017, N63, p. 95-106. The original publication is available at http://www.sciencedirect.com http://dx.doi.org/10.1016/j.eiar.2016.12.004

\begin{tabular}{|c|c|c|c|c|}
\hline $\begin{array}{l}\text { Identification } \\
\text { of key impacts }\end{array}$ & $\begin{array}{l}\text { Water body } \\
\text { quality } \\
\text { Impacts on } \\
\text { fauna, flora, } \\
\text { landscape }\end{array}$ & $\begin{array}{c}\text { Climate change } \\
\text { Fossil, metal, water } \\
\text { depletion } \\
\text { Human toxicity } \\
\text { Particulate matter formation } \\
\text { Land Occupation } \\
\text { Eutrophication }\end{array}$ & $\begin{array}{l}\text { Water body quality } \\
\text { Impacts on fauna, } \\
\text { flora, landscape }\end{array}$ & $\begin{array}{c}\text { Climate change } \\
\text { Fossil, metal, water depl. } \\
\text { Human toxicity } \\
\text { Particulate matter form. } \\
\text { Land Occupation } \\
\text { Eutrophication }\end{array}$ \\
\hline \multirow[b]{2}{*}{$\begin{array}{l}\text { Step 3-b: } \\
\text { Impact } \\
\text { Assessment }\end{array}$} & \multicolumn{4}{|c|}{$\begin{array}{l}\text { LCA gives crucial additional information to current EIA: } \\
\text { Highlights more impacts, especially global ones (e.g., climate change) } \\
\text { 2) Adds information on the processes responsible for the impacts } \\
\text { 3) Assesses off-site impacts due to background activities }\end{array}$} \\
\hline & $\begin{array}{l}\text { Identification } \\
\text { of main local } \\
\text { pressures/ } \\
\text { concerns } \\
\text { (qualitative): } \\
\text { (i) Major } \\
\text { concern: water } \\
\text { pollution and } \\
\text { flows, land } \\
\text { transformation } \\
\text { (ii) Mean } \\
\text { concern: noise } \\
\text { and odour }\end{array}$ & $\begin{array}{l}\text { 1-Quantification of the } \\
\text { impacts (local and global): } \\
\text { climate change, urban land } \\
\text { occupation, fossil depletion } \\
\text { 2-Contribution analysis } \\
\text { (background /foreground } \\
\text { activities), e.g., climate } \\
\text { change essentially due to } \\
\text { the on-site discharges of the } \\
\text { WWTP }\end{array}$ & $\begin{array}{l}\text { Identification } \\
\text { of main local } \\
\text { pressures/ } \\
\text { concerns } \\
\text { (qualitative) } \\
\text { (i) Major } \\
\text { concern: water } \\
\text { pollution, land } \\
\text { transformation, } \\
\text { landscape } \\
\text { (ii) Mean } \\
\text { concern: noise }\end{array}$ & $\begin{array}{l}\text { 1-Quantification of the } \\
\text { impacts (local and global): } \\
\text { climate change, fossil } \\
\text { depletion } \\
\text { 2-Contribution analysis } \\
\text { (background /foreground } \\
\text { activities), e.g., climate } \\
\text { change essentially due to the } \\
\text { on-site discharges of the } \\
\text { WWTP }\end{array}$ \\
\hline \multirow{2}{*}{$\begin{array}{l}\text { Step 4: } \\
\text { Mitigation } \\
\text { measures }\end{array}$} & \multicolumn{2}{|r|}{ Different } & \multicolumn{2}{|r|}{ Different } \\
\hline & $\begin{array}{l}\text { Impacts of } \\
\text { measures not } \\
\text { analysed }\end{array}$ & Impacts assessed & $\begin{array}{l}\text { Impacts of } \\
\text { measures not } \\
\text { analysed }\end{array}$ & Impacts assessed \\
\hline
\end{tabular}

471 In our case studies, the choice of alternatives is based on either technical conditions or land

472 pressure, and the EIA does not report the environmental impacts of all technologies. For case

473 study 1, the preferred technology turns out to be the same with or without LCA inputs, even if

474 one conclusion is based on environmental profiles and the other one on technical constraints.

475 For case study 2, the conclusions differ because of the environmental pressure on protected

476 areas specific to the case study 2 location. In this case, a different technology would have

477 been chosen when only looking at the LCA profile. Thus, to provide a complete picture of the

478 actual environmental impacts, environmental profiles should be interpreted in the light of 479 specific local conditions. 
480

481

482

483

484

485

486

487

488

489

490

491

492

493

494

495

496

497

498

499

500

501

502

503

504

505

506

507

508

509

For step 2-b, the selected environmental concerns are essentially different. Furthermore, the scoping method without LCA is mainly implicit and based on the expertise of the EIA practitioners, whereas it is based on the LCA results for the EIA with LCA. In the EIA Directive 2014/52/EU (Official Journal of the European Union, 2014), the panorama of impacts is wide: population, human health, biodiversity (e.g., fauna and flora), land, soil (e.g., organic matter, erosion, compaction, sealing), water (e.g., hydromorphological changes, quantity and quality), air, climate (e.g., greenhouse gas emissions and impacts relevant to adaptation), material assets, cultural heritage, including architectural and archaeological aspects, and landscape. Nevertheless, in the case studies considered, the impact of the project on climate change (e.g., the nature and magnitude of greenhouse gas emissions) is not assessed, despite the fact that this aspect is becoming increasingly important in recent legislation and in societal concerns. In contrast, regarding the nature of the impacts, unlike current LCA methodologies, EIA usually addresses natural and technological risks and neighbourhood disturbances such as noise or odour, which are very important for the public acceptability of projects.

For the impact assessment (step 3-b), the main difference between the EIAs with or without LCA lies in the calculation of the impacts itself. EIA mainly identifies local pollution sources or pressures (qualitative/quantitative assessment), whereas LCA always calculates the total potential impacts (quantitative assessment). In principle, EIA should cover the direct effects and any indirect, secondary, cumulative, transboundary, short-term, medium-term and longterm, permanent and temporary, and positive and negative effects of a project (Official Journal of the European Union, 2014). However, in the case studies (without LCA), only onsite impacts were identified, and all off-site (or indirect) impacts were missing. Adding LCA helps to highlight more impacts, especially global impacts and off-site impacts, and gives information on the processes responsible for them.

For step 4, the conclusions of the EIAs with or without LCA clearly differed due to the missing consideration of the impacts of the implementation of mitigation measures in the current EIA studies (without LCA).

The interest of LCA for EIA studies has been demonstrated on two case studies, but some methodological and practical bottlenecks remain. 


\subsection{Differences in scopes and impact assessment calculations between EIA and LCA} The main methodological issue for the implementation of LCA in EIA would be the difference in scopes and boundaries of the studied system between them. The EIA scope only includes on-site impacts but forecasts them under normal and degraded conditions (extreme climatic or water conditions in our case studies). Conversely, the LCA scope covers on-site and off-site impacts but only in a normal mode of operation. Note that sludge end-of-life is generally planned in the EIA (agricultural spreading in the case studies), but it falls outside the EIA scope because the associated impacts are not taken into account (Figure 7).

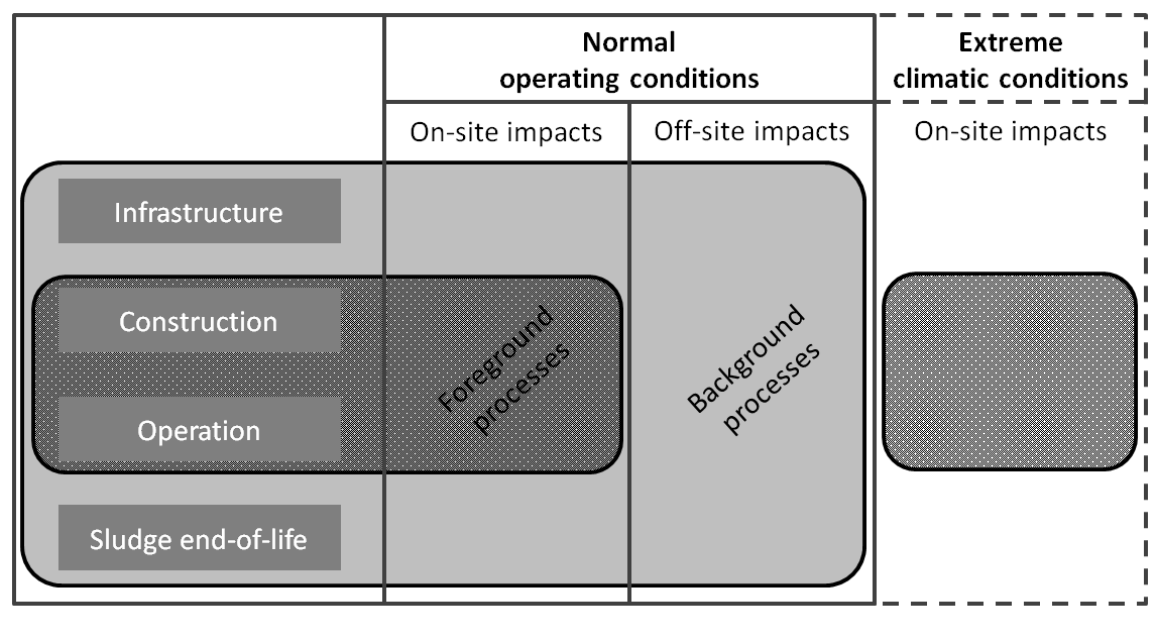

Figure 7: Scopes of the EIA and LCA approaches

Temporal boundaries also differ; for example, in the case studies, the impacts related to the WWTP construction site were identified as of a "temporary nature" because of the temporary nature of the construction, whereas the impacts occurring during normal operation of the WWTP were defined as "permanent or temporary". However, in LCA, temporary phases of a process (e.g., civil engineering works) can prove to have longer term effects because impacts such as resource depletion or climate change are considered. Regarding their study object and focus, EIA evaluates the impact of concrete projects, whereas LCA is tailored to draw the performance of product and service systems for a large range of impacts (Potting et al., 2012). For EIA, importing impact characterisation techniques from LCA would imply that the study object and focus in EIA might encompass the study object and focus of LCA. EIA generally addresses local impacts (e.g., air and water pollution, landscape change, and noise) and is supposed to choose the most appropriate methods regarding the uniqueness of the site and the selected impacts. The EIA spatial boundaries stay generally within a regional area ("the site and its environment"). As a consequence, the choice of issues relevant for these restricted 
534 boundaries may lead to neglecting significant off-site impacts. In EIA case studies, global 535 impacts (e.g., climate change, resource depletion, and ozone depletion) are poorly considered, even if they are due to on-site activities. A recent study analysed approximately 1700 Spanish environmental records of decision (RODs) for projects submitted for EIA and concluded that on average climate change is considered in only $14 \%$ of them, half of them only "citing" it (Enríquez-de-Salamanca et al., 2016). As displayed in Figure 6 and Figure S 7, among the impacts assessed with LCA, the assessment of current EIA studies only addresses the on-site and local/regional impacts (uniform light-grey for on-site impacts). However, as stressed in the last section (3.3), in regulatory decrees the scope of EIA tends to become wider (Official Journal of the European Union, 2014). As a consequence, current EIA boundaries usually considered by EIA practitioners should definitively be extended to allow the assessment of off-site impacts (with LCA).

In other words, EIA could, such as LCA, consider the whole planet as a place for potential impacts (no boundaries) and include (i) global impacts and (ii) off-site impacts. In this sense, some recent EIA projects with potential significant $\mathrm{CO}_{2}$ emissions (in particular, energy and transportation projects) and for which energy efficiency is a key issue, such as building projects, tend to include energy and climate change indicators (European Commission, 2009). Specific analytical tools can assess greenhouse gas emissions (e.g., Bilan Carbone ${ }^{\circledR}$ from the French environment and energy management agency ADEME), but LCA goes further on climate change causality (damages to ecosystems and human health) and covers a more holistic range of environmental problems. However, although they generally provide a complete quantification of net environmental impacts from a regional (e.g., eutrophication, acidification, and ecotoxicity) or global perspective (e.g., climate change), standard LCIA methods do not address local concerns such as neighbourhood nuisances or landscape integration of projects. Moreover, the EIA framework, which is typically designed for a sitespecific assessment, not only has to take into account the specific local geographic situation but should also evaluate the existing background pressure on the environment (Jeswani et al., 2010), whereas LCIA methods only assess additional impact contributions.

562 One should also be aware that the term "impact assessment" has different meanings in EIA 563 and LCA. LCA always calculates a potential impact assuming the presence of a target. For 564 EIA studies, there is more information on the presence or absence of a target; thus, the estimated risk in EIA is assessed by crossing the hazard identification with a real exposure quantification (Thabrew et al., 2009). Exposure is non-existent if there is no potentially 
affected target. Furthermore, mitigation measures can remove exposure and consequently remove risk (even if the hazard, pollution for example, is still there). Most of the time, current practice in EIA consists of identifying the risk but not in assessing quantitative consequences/impacts of that risk. Consequently, for more consistency between the methods, the definition of "impact" would have to be aligned.

\subsection{Practical feasibility of combining EIA and LCA}

573 A more practical bottleneck for the proposed methodology is that EIA and LCA are 574 developed and used by two rather different communities of scientists and practitioners and are often used in different contexts (Tukker, 2000). A combined use of several tools would require a more comprehensive interdisciplinary approach to align the different tool characteristics and focuses (Buytaert et al., 2011). Even if researchers are open to building bridges between these two disciplines, in practice, an EIA practitioner has rarely both EIA expertise and LCA modelling skills. EIA consultancy firms could hire the services of LCA subcontractors, but the production cost of such an EIA study would increase and may not fit into the global budget. With a wider scope than current EIA studies, more quantitative data are needed for LCA, and data collection can prove to be both time-consuming and costly. The estimated cost ranges from $10 \mathrm{k} €$ to $100 \mathrm{k} €$ for products for which databases covering a large part of the life cycle already exist (Boeglin and Veuillet, 2005). If the emission and resource use data are particularly specific and not previously collected as inventory, the LCA cost can exceed a hundred thousand euros. On the other hand, according to a study conducted for the European Commission (GHK, 2010), the EIA cost to a developer in the EU is approximately $1 \%$ of the project cost, with an average cost of $53 \mathrm{k} €$. The French environmental institution CGEDD estimates that cost ranges from a few thousand euros for the simplest studies up to several million euros for impact assessments of major rail and highway infrastructures (Lavoux and Féménias, 2011). Thus, the orders of magnitude of EIA and LCA costs appear to be similar. Consequently, the extra cost for performing an LCA would be a significant additional cost for EIA consultants and could at least double the current price of EIA studies. This bottleneck could be approached with the use of simplified LCA softwares such as the ACV4E software (http://acv4e.irstea.fr) developed by the French research institute IRSTEA and designed for local WWTP actors. With that kind of simplified LCAs, the time and cost of an LCA implementation could be significantly reduced.

598 Moreover, the appropriation and the potential use of this procedure by the EIA practitioners would be a second-stage or practical implementation that needs to be studied in the future. 
Author-produced version of the article published in Environmental Impact Assessment Review, 2017, N63, p. 95-106.

The original publication is available at http://www.sciencedirect.com

http://dx.doi.org/10.1016/j.eiar.2016.12.004

600

601

602

603

604

605

606

607

608

609

610

611

612

613

614

615

616

617

618

619

620

621

622

623

624

625

626

627

628

629

630

631

\subsection{Towards a generic methodology}

The objective of the paper was to test the applicability of the proposed methodology on a real case study. Although a high share of European EIA studies address infrastructure projects such as energy, transport, water management and waste management (GHK, 2010), one can still question if the selected case studies are representative of overall EIA practice, and thus if the proposed procedure can easily be applied to other types of projects. The general EIA process was designed to fit all types of public and private projects; thus our procedure could also be useful for installations and projects other than WWTPs. This is why we applied the framework to a project involving contrasted technical solutions (from extensive ones such as red bed filters to more intensive ones) and strong local pressures on the environment (freshwater in our case), which is common for many projects subject to EIA. Nevertheless, after this first step of implementation, the feasibility of and interest in the proposed procedure will need to be tested and validated on several other types of projects.

\section{Conclusions and perspectives}

A literature review demonstrated that many authors foresaw and discussed the theoretical benefits of LCA for EIA, but the review also revealed a lack of applied research on the subject. Thus, a methodology for implementing LCIA in four specific steps of the EIA procedure was proposed, i.e., the choice of alternatives, identification of key impacts, project impact assessment and mitigation measures. The use of LCA led to significant differences and justified the interest in combining both approaches. Even if the conclusions of EIAs with or without LCA were partially common, especially for local on-site impacts, LCA provided crucial additional information. The LCA approach allowed (i) a comparison of alternatives on environmental criteria, ii) the addition of information on the processes responsible for the impacts, (iii) a consideration of additional impacts, especially global impacts (e.g., climate change or resource depletion), and (iv) an assessment of off-site impacts due to background activities. The LCA-EIA results on the WWTP case studies showed that to improve the quality of local water bodies (e.g., eutrophication or ecotoxicity), significant impacts on other categories and in other places can be generated (e.g., climate change associated with energy production). LCA expanded the scope of the assessment and identified pollution transfers towards a life cycle perspective.

Nonetheless, the question arises as to whether local/regional or global impacts and on-site or off-site impacts are given the same weight in decision-making for project developers. Local 
632 impacts and neighbourhood disturbances occurring on-site are essential for project 633 acceptability, but over the last decade, global environmental issues such as resource 634 sustainability and climate change have also become more important in policy making 635 (Official Journal of the European Union, 2014). However, more generally, the link between 636 "provided information" and "decision-making" is not always straightforward, and more 637 research, e.g., through the introduction of management sciences in the LCA field, should 638 better study the use of LCA as an environmental assessment tool to support public decision639 making.

640 In terms of applicability, potential bottlenecks for the widespread use of the methodology 641 were identified, and recommendations to address such operational limitations were proposed.

642 Finally, there is room to improve the proposed methodological framework, especially by 643 strengthening the relevance of LCIA methods for impact assessment in EIA. Given the very 644 specific and local nature of industrial projects subject to EIA legislation, one important 645 weakness of current LCIA methods is their limited consideration of local specificities. 646 Another potential major lever is the improvement of various environmental pathways. For 647 example, to date, LCIA methods have poor or no consideration of certain environmental 648 issues such as natural and technological risks and neighbourhood nuisances. However, current 649 LCIA research is working to improve this situation.

\section{Acknowledgements}

651 The authors thank David Salze for his good advice on the subject. The authors are members of 652 the ELSA research group (Environmental Life Cycle and Sustainability Assessment, 653 http://www.elsa-lca.org/) and thank all ELSA members for their advice. This work was 654 supported by the French National Research Agency (ANR), the Languedoc-Roussillon 655 Region, ONEMA, Ecole des mines d'Alès and the industrial partners (BRL, SCP, SUEZ, 656 VINADEIS, and Compagnie Fruitière) of the Industrial Chair for Environmental and Social 657 Sustainability Assessment "ELSA-PACT” (ANR grant no. 13-CHIN-0005-01).

\section{Funding sources}

659 The French National Research Agency ANR (grant no. 13-CHIN-0005-01), the Languedoc660 Roussillon Region, ONEMA, Ecole des mines d'Alès, industrial partners BRL, SCP, SUEZ, 661 VINADEIS, Compagnie Fruitière of the Industrial Chair for Environmental and Social 662 Sustainability Assessment "ELSA-PACT". 


\section{References}

664

665

666

667

668

669

670

671

672

673

674

675

676

677

678

679

680

681

682

683

684

685

686

687

688

689

690

691

692

693

694

695

696

697

698

699

700

701

702

703

Alexandre, O., Boutin, C., Duchène, P., Lagrange, C., Lakel, A., Liénard, A., Orditz, D., 1998. Filières d'épuration adaptées aux petites collectivités - Document technique FNDAE n ${ }^{\circ} 22$, First. ed. Publi-Trans.

Bidstrup, M., 2015. Life cycle thinking in impact assessment-Current practice and LCA gains. Environ. Impact Assess. Rev. 54, 72-79. doi:10.1016/j.eiar.2015.05.003

Bidstrup, M., Pizzol, M., Schmidt, J.H., 2015. Life Cycle Assessment in spatial planning e A procedure for addressing systemic impacts. J. Clean. Prod. 91, 136-144. doi:10.1016/j.jclepro.2014.12.027

Björklund, A., 2012. Life cycle assessment as an analytical tool in strategic environmental assessment . Lessons learned from a case study on municipal energy planning in Sweden. Environ. Impact Assess. Rev. 32, 82-87. doi:10.1016/j.eiar.2011.04.001

Boeglin, N., Veuillet, D., 2005. Introduction à l'Analyse de Cycle de Vie (ACV) - Note de synthèse externe ADEME.

Boutin, C., Lienard, A., Molle, P., 2007. Les filtres plantés de roseaux , le lagunage naturel et leurs associations : comment? pourquoi ? Sinfotech - Les fiches Savoir-faire 1-6.

Buytaert, V., Muys, B., Devriendt, N., Pelkmans, L., Kretzschmar, J.G., Samson, R., 2011. Towards integrated sustainability assessment for energetic use of biomass: A state of the art evaluation of assessment tools. Renew. Sustain. Energy Rev. 15, 3918-3933. doi:10.1016/j.rser.2011.07.036

Choubert, M., Martin-Ruel, S., Budzinski, H., Miège, C., Esperanza, M., Soulier, C., Lagarrigue, C., Coquery, M., 2011. Évaluer les rendements des stations d'épuration Apports méthodologiques et résultats pour les micropolluants en filières conventionnelles et avancées. Tech. Sci. Méthodes $n^{\circ} 1 / 2$.

Cornejo, F., Janssen, M., Gauldreault, C., Samson, R., Stuart, P.R., 2005. Using Life Cycle Assessment (LCA) as a Tool to Enhance Environmental Impact Assessments (EIA). Chem. Eng. Trans. 7, 521-528.

Enríquez-de-Salamanca, Á., Martín-aranda, R.M., Díaz-sierra, R., 2016. Consideration of climate change on environmental impact assessment in Spain. Environ. Impact Assess. Rev. 57, 31-39. doi:10.1016/j.eiar.2015.11.009

EPNAC, 2015. Ouvrages de traitement par filtres plantés de roseaux - Guide d'exploitation, First. ed. ONEMA.

European Commission, 2009. Study concerning the report on the application and effectiveness of the EIA Directive - Final report.

European Commission, 2001. Guidance on EIA - Scoping. European Communities, Luxembourg.

European Commission, JRC, IES, 2010a. ILCD Handbook: Analysis of existing Environmental Impact Assessment methodologies for use in Life Cycle Assessment, First. ed.

European Commission, JRC, IES, 2010b. ILCD Handbook: Framework and requirements for LCIA models and indicators, First. ed. doi:10.2788/38719

Finnveden, G., Hauschild, M.Z., Ekvall, T., Guinée, J., Heijungs, R., Hellweg, S., Koehler, A., Pennington, D., Suh, S., 2009. Recent developments in Life Cycle Assessment. J. 
Environ. Manage. 91, 1-21. doi:10.1016/j.jenvman.2009.06.018

Finnveden, G., Moberg, A., 2005. Environmental systems analysis tools - an overview. J. Clean. Prod. 13, 1165-1173. doi:10.1016/j.jclepro.2004.06.004

Finnveden, G., Nilsson, M., Johansson, J., Persson, Å., Moberg, A., Carlsson, T., 2003. Strategic environmental assessment methodologies - applications within the energy sector. Environ. Impact Assess. Rev. 23, 91-123.

GHK, 2010. Collection of information and data to support the Impact Assessment study of the review of the EIA Directive - Final report.

Goedkoop, M., Heijungs, R., Huijbregts, M., de Schryver, A., Struijs, J., Van Zelm, R., 2013. ReCiPe 2008 - First edition (revised) - Report I: Characterisation. Ministerie van VROM.

Golla, G., Petit, K., Hocquet, C., 2010. Bilan 2008 de l'assainissement en France. ONEMA.

IAIA, IEA, 1999. Principles of Environmental Impact Assessment best practice.

ISO, 2014. ISO/TS 14072:2014 - Environmental management — Life cycle assessment -

ISO, 2006a. ISO 14040:2006 - Environmental management - Life cycle assessment Principles and framework.

ISO, 2006b. ISO 14044:2006 - Environmental management - Life cycle assessment Requirements and guidelines.

Jeswani, H.K., Azapagic, A., Schepelmann, P., Ritthoff, M., 2010. Options for broadening and deepening the LCA approaches. J. Clean. Prod. 18, 120-127. doi:10.1016/j.jclepro.2009.09.023

Lavoux, T., Féménias, A., 2011. Compétences et professionnalisation des bureaux d'études au regard de la qualité des études d'impact (évaluations environnementales) - Rapport n007411-01. Conseil Général de 1'Environnement et du Développement Durable (CGEDD).

Lenzen, M., Murray, S. a., Korte, B., Dey, C.J., 2003. Environmental impact assessment including indirect effects - a case study using input-output analysis. Environ. Impact Assess. Rev. 23, 263-282. doi:10.1016/S0195-9255(02)00104-X

Liénard, A., Boutin, C., Molle, P., Racault, Y., Brissaud, F., Picot, B., 2004. Filtres plantés de roseaux à flux vertical et lagunage naturel en traitement d'eaux usées domestiques en France : comparaison des performances et des contraintes d'exploitation en termes de pérennité et fiabilité. Ingénieries 87-99.

M.A.G.E. 42, 2007. Stations d'épuration des petites collectivités - Recommandations issues du retour d'expérience M.A.G.E. Conseil Général de la Loire.

Macrophytes et Traitement des Eaux, 2005. Epuration des eaux usées domestiques par filtres plantés de macrophytes - Recommandations techniques pour la conception et la réalisation. Agence de l'eau Rhône Méditerranée \& Corse.

Manuilova, A., Suebsiri, J., Wilson, M., 2009. Should Life Cycle Assessment be part of the Environmental Impact Assessment? Case study: EIA of CO2 Capture and Storage in Canada. Energy Procedia 1, 4511-4518. doi:10.1016/j.egypro.2009.02.269

Molle, P., Prost-Boucle, S., Lienard, A., 2008. Potential for total nitrogen removal by combining vertical flow and horizontal flow constructed wetlands: A full-scale 
experiment study. Ecol. Eng. 34, 23-29. doi:10.1016/j.ecoleng.2008.05.016

Morero, B., Rodriguez, M.B., Campanella, E.A., 2015. Environmental impact assessment as a complement of life cycle assessment. Case study: Upgrading of biogas. Bioresour. Technol. 190, 402-407. doi:10.1016/j.biortech.2015.04.091

Official Journal of the European Union, 2014. Directive 2014/52/EU of the European Parliament and of the Council of 16 April 2014 amending Directive 2011/92/EU on the assessment of the effects of certain public and private projects on the environment.

Ogola, P.F.A., 2007. Environmental Impact Assessment General procedures, Short Course II on Surface Exploration for Geothermal Resources, organized by UNU-GTP and KenGen. Lake Naivasha, Kenya.

Potting, J., Gheewala, S., Bonnet, S., van Buuren, J., 2012. How to Approach the Assessment?, in: Curran, M.A. (Ed.), Life Cycle Assessment Hanbook - A Guide for Environmentally Sustainable Products. Scrivener Publishing, pp. 391-412.

Racault, Y., Bois, J.-S., Carré, J., Duchêne, P., Lebaudy, B., Lesavre, J., Lickel, P., Rateau, M., Vachon, A., 1997. Le Lagunage naturel - Les leçons titées de 15 ans de pratique en France. Publi-Trans.

Risch, E., Gutierrez, O., Roux, P., Boutin, C., Corominas, L., 2015. Life cycle assessment of urban wastewater systems: Quantifying the relative contribution of sewer systems. Water Res. 77, 35-48. doi:10.1016/j.watres.2015.03.006

Risch, E., Loubet, P., Núñez, M., Roux, P., 2014. How environmentally significant is water consumption during wastewater treatment? : Application of recent developments in LCA to WWT technologies used at 3 contrasted geographical locations. Water Res. doi:10.1016/j.watres.2014.03.023

SDEA, 2013. Rapport annuel sur le prix et la qualité du service public d'assainissement Année 2012. Syndicat des Eaux et de l'Assainissement du Bas-Rhin.

Steinemann, A., 2001. Improving alternatives for environmental impact assessment. Environ. Impact Assess. Rev. 21, 3-21. doi:10.1016/S0195-9255(00)00075-5

Thabrew, L., Wiek, A., Ries, R., 2009. Environmental decision making in multi-stakeholder contexts: applicability of life cycle thinking in development planning and implementation. J. Clean. Prod. 17, 67-76. doi:10.1016/j.jclepro.2008.03.008

Tukker, A., 2000. Life cycle assessment as a tool in environmental impact assessment. Environ. Impact Assess. Rev. 20, 435-456.

UNEP, 2002. Impact analysis, in: Sadler, B., McCabe, M. (Eds.), EIA Training Resource Manual - Second Edition. UNEP, pp. 253-298.

von Sperling, M., 2007. Waste Stabilisation Ponds, in: Biological Wastewater Treatment in Warm Climate Regions. IWA Publishing, pp. 1-162.

Židonienè, S., Kruopienė, J., 2014. Life Cycle Assessment in environmental impact assessments of industrial projects: towards the improvement. J. Clean. Prod. doi:10.1016/j.jclepro.2014.07.081 


\section{Supplementary material}

\section{List of Tables}

Table S 1: Brief description of the case studies and main information on the first three steps of

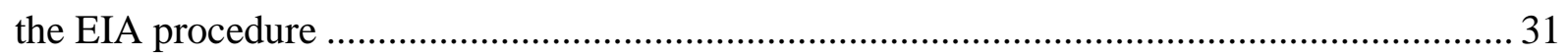

Table S 2: Initial state of the environment for the two case studies ....................................... 32

Table S 3: Impact assessment and proposed mitigation measures for the two case studies .... 32

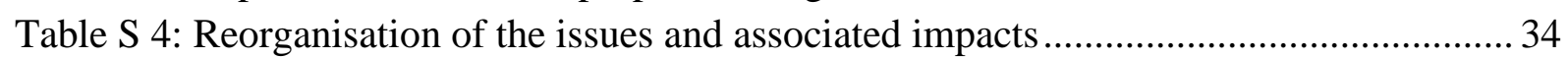

Table S 5: Description of WWTPs Life Cycle Inventories (LCI) .......................................... 35

Table S 6: Selected inventory data for the WWTP model ................................................... 36

Table S 7: Description of the implementation of mitigation measures modelled (LCI) .......... 37

Table S 8: Issues considered within the existing EIA and proposed rating for the two case studies.....

The EIA documents were available in French during the public consultation phase at www.alsace.developpement-durable.gouv.fr.

Table S 1: Brief description of the case studies and main information on the first three steps of the EIA procedure

\begin{tabular}{|c|c|c|}
\hline & Case study 1 (CS 1) & Case study 2 (CS 2) \\
\hline City & Altwiller & Obersteinbach / Niedersteinbach \\
\hline Region & Alsace & Alsace \\
\hline Project & \multicolumn{2}{|l|}{ To collect and treat wastewater } \\
\hline $\begin{array}{l}\text { Goal and scope of the } \\
\text { EIA }\end{array}$ & \multicolumn{2}{|c|}{$\begin{array}{l}\text { Upgrading or rebuilding WWTP to fulfill Water Framework Directive and } \\
\text { population growth. }\end{array}$} \\
\hline Main dates & $\begin{array}{l}\text { EIA report: } 17 / 11 / 2011 \\
\text { Put into use: } 25 / 07 / 2013\end{array}$ & $\begin{array}{l}\text { EIA report: } 20 / 01 / 2011 \\
\text { Put into use: } 30 / 07 / 2013\end{array}$ \\
\hline Technical constraints & $\mathrm{DBO}_{5}: 26.4 \mathrm{~kg} / \mathrm{day}$ & $\mathrm{DBO}_{5}: 41 \mathrm{~kg} /$ day \\
\hline $\begin{array}{l}\text { Environmental } \\
\text { constraints }\end{array}$ & Phosphorus and nitrogen sensitivity & $\begin{array}{l}\text { Natura } 2000 \\
\text { Phosphorus and nitrogen sensitivity }\end{array}$ \\
\hline $\begin{array}{l}\text { Main documents (see } \\
\text { supporting } \\
\text { information) }\end{array}$ & $\begin{array}{l}\text { EIA report, prefectural order, soil and } \\
\text { water expertise }\end{array}$ & $\begin{array}{l}\text { EIA report, prefectural order, Natura } \\
2000 \text { impact report }\end{array}$ \\
\hline $\begin{array}{l}\text { Screening } \\
\text { (EIA - step 1) }\end{array}$ & \multicolumn{2}{|c|}{$\begin{array}{l}\text { All wastewater treatment plants of local municipalities of a capacity inferior to } \\
10000 \text { population equivalents have to provide an environmental impact statement (a } \\
\text { final report summarising the EIA) according to French regulation (see Articles } \\
\text { R.122-5 and R.122-6 of environmental code) }\end{array}$} \\
\hline $\begin{array}{l}\text { Alternatives identified } \\
\text { during scoping (EIA - } \\
\text { step 2-a) }\end{array}$ & $\begin{array}{l}\text { Centralised WWTP with different } \\
\text { technological processes, i.e., i) vertical } \\
\text { Reed Bed Filters (vRBF), ii) Activated } \\
\text { Sludge (AS) and } \text { iii) Infiltration- } \\
\text { Percolation (IP) }\end{array}$ & $\begin{array}{l}\text { Centralised WWTP with different } \\
\text { technological processes, i.e., i) vertical } \\
\text { or horizontal Reed Bed Filters } \\
\text { (respectively vRBF and hRBF), ii) } \\
\text { Activated Sludge or Activated Sludge } \\
\text { Sequencing Batch Reactor (AS and AS- }\end{array}$ \\
\hline
\end{tabular}




\begin{tabular}{|c|c|c|}
\hline & & $\begin{array}{l}\text { SBR), iii) Naturally Aerated Lagoons } \\
\text { (NL) iv) Artificially Aerated Lagoons } \\
\text { (AL), v) Biological Disks (BD), and vi) } \\
\text { Infiltration-Percolation (IP) }\end{array}$ \\
\hline $\begin{array}{l}\text { Justification of the } \\
\text { chosen system }\end{array}$ & $\begin{array}{l}\text { Reed bed filters were chosen because of } \\
\text { the effluent volume to be treated, the } \\
\text { required treatment levels especially for } \\
\mathrm{N} \text {, the low operation costs, the } \\
\text { integration into the landscape, the } \\
\text { easiness to operate, and the low sub- } \\
\text { product production. }\end{array}$ & $\begin{array}{l}\text { Activated sludge process was selected } \\
\text { because of the effluent volume to be } \\
\text { treated, its high treatment efficiency and } \\
\text { its reduced area requirement that } \\
\text { minimises its impacts on the Natura } \\
2000 \text { area. }\end{array}$ \\
\hline $\begin{array}{l}\text { Scoping - } \\
\text { identification of key } \\
\text { impacts } \\
\text { (EIA - step 2-b) }\end{array}$ & \multicolumn{2}{|c|}{$\begin{array}{l}\text { The spatial boundaries are those of the projects and the downstream watershed. } \\
\text { Temporal boundaries are defined in two phases, i.e., the civil engineering works and } \\
\text { the period of operation. } \\
\text { Two main environmental issues implicitly emerged, i.e., water body quality and the } \\
\text { impacts due to civil engineering works on fauna, flora, landscape... }\end{array}$} \\
\hline
\end{tabular}

Table S 2: Initial state of the environment for the two case studies

\begin{tabular}{|c|c|c|c|}
\hline & & Case study 1 & Case study 2 \\
\hline & Issues & State & State \\
\hline \multirow{7}{*}{$\begin{array}{l}\text { Baseline description of } \\
\text { the initial } \\
\text { environmental state } \\
\text { (EIA - step 3-a) }\end{array}$} & $\begin{array}{l}\text { Location / } \quad \text { Weather } \\
\text { Geology / Hydrogeology }\end{array}$ & Description & Description \\
\hline & $\begin{array}{ll}\text { Receiving } & \text { environment: } \\
\text { Water quality } & \end{array}$ & $\begin{array}{l}\text { Fair to poor quality (for } \\
\text { nitrogen and phosphor } \\
\text { parameters) identified }\end{array}$ & $\begin{array}{l}\text { Good ecological status } \\
\text { identified }\end{array}$ \\
\hline & Earthquake risks & No risk identified & No risk identified \\
\hline & Flood risks & No risk identified & No risk identified \\
\hline & Fauna and flora & $\begin{array}{l}\text { Potential wetland of } \\
\text { low interest }(0,4 \mathrm{ha})\end{array}$ & $\begin{array}{l}\text { Natura } 2000 \text { area with } \\
\text { species of community } \\
\text { interest }\end{array}$ \\
\hline & Abstraction of drinking water & None & None \\
\hline & Human environment & $\begin{array}{l}\text { First residences at } 300 \\
\mathrm{~m}\end{array}$ & First residence at $150 \mathrm{~m}$ \\
\hline
\end{tabular}

Table S 3: Impact assessment and proposed mitigation measures for the two case studies

\begin{tabular}{|l|l|l|l|l|l|}
\hline & \multicolumn{3}{|l|}{ Case study 1 } & \multicolumn{2}{l|}{ Case study 2 } \\
\hline & Issues & Impacts & $\begin{array}{l}\text { Corrective/ } \\
\text { Mitigation } \\
\text { measures }\end{array}$ & Impacts & $\begin{array}{l}\text { Corrective/ } \\
\text { Mitigation } \\
\text { measures }\end{array}$ \\
\hline $\begin{array}{l}\text { Impacts on the } \\
\text { receiving } \\
\text { environment (EIA } \\
\text { - step 3-b1) }\end{array}$ & Water flows & $\begin{array}{l}\text { Low stream } \\
\text { flow: stagnation } \\
\text { of plant flow }\end{array}$ & $\begin{array}{l}\text { Reshaping the } \\
\text { ditch to } \\
\text { improve water } \\
\text { flow + } \\
\text { maintenance }\end{array}$ & None & No measure \\
\cline { 2 - 6 } & Dry weather & $\begin{array}{l}\text { Decreasing of } \\
\text { self-purification } \\
\text { Class of state } \\
\text { "Mean" }\end{array}$ & $\begin{array}{l}\text { Plant sizing to } \\
\text { perform a } \\
\text { more rigorous } \\
\text { water } \\
\text { treatment for } \\
\text { COD, BOD } \\
\text { and NH }{ }_{5}^{+}\end{array}$ & $\begin{array}{l}\text { Issues with } \\
\text { phosphor } \\
\text { and } \\
\text { suspended } \\
\text { matter }\end{array}$ & $\begin{array}{l}\text { Activated sludge } \\
\text { allows better } \\
\text { performance than } \\
\text { required and setup of } \\
\text { a sludge blanket } \\
\text { detector }\end{array}$ \\
\cline { 2 - 6 } & Wet weather & Insufficient & Corrective & Identical to & No measure \\
\hline
\end{tabular}


Author-produced version of the article published in Environmental Impact Assessment Review, 2017, №63, p. 95-106.

The original publication is available at http://www.sciencedirect.com

http://dx.doi.org/10.1016/j.eiar.2016.12.004

\begin{tabular}{|c|c|c|c|c|c|}
\hline & & $\begin{array}{l}\text { dilution capacity } \\
\text { of the } \\
\text { environment }\end{array}$ & $\begin{array}{l}\text { measure: Plant } \\
\text { sizing to } \\
\text { strengthen } \\
\text { rainwater } \\
\text { treatment (a } \\
\text { fraction of } \\
\text { rainwater) }\end{array}$ & $\begin{array}{l}\text { dry weather } \\
\text { (separate } \\
\text { sewer } \\
\text { system) }\end{array}$ & \\
\hline & $\begin{array}{l}\text { Civil } \\
\text { engineering } \\
\text { works }\end{array}$ & $\begin{array}{l}\text { Risks for } \\
\text { suspended } \\
\text { matter }\end{array}$ & $\begin{array}{l}\text { Excavated } \\
\text { area } \\
\text { reconditioning }\end{array}$ & $\begin{array}{l}\text { Risks for } \\
\text { suspended } \\
\text { matter }\end{array}$ & $\begin{array}{l}\text { Civil engineering } \\
\text { works during summer } \\
+ \text { operation from } \\
\text { river banks }\end{array}$ \\
\hline & $\begin{array}{l}\text { Incident / } \\
\text { Accident }\end{array}$ & $\begin{array}{l}\text { Low risk of } \\
\text { accidental } \\
\text { release }\end{array}$ & $\begin{array}{l}\text { Isolation } \\
\text { valves }\end{array}$ & $\begin{array}{l}\text { Low risk of } \\
\text { accidental } \\
\text { release }\end{array}$ & Isolation valves \\
\hline \multirow{4}{*}{$\begin{array}{l}\text { Impacts on the site } \\
\text { during civil } \\
\text { engineering works } \\
\text { (EIA -step 3-b2) }\end{array}$} & $\begin{array}{l}\text { Human } \\
\text { environment }\end{array}$ & Noise & No measure & None & No measure \\
\hline & \multirow[t]{3}{*}{$\begin{array}{l}\text { Natural } \\
\text { environment }\end{array}$} & $\begin{array}{l}\text { Indirect impacts } \\
\text { on downstream } \\
\text { wetland of high } \\
\text { interest due to } \\
\text { sewage pipe } \\
\text { laying }\end{array}$ & Clay plugs & \multirow[t]{3}{*}{$\begin{array}{l}\text { Natura } 2000 \\
\text { perimeter } \\
\text { but outside } \\
\text { of habitats of } \\
\text { community } \\
\text { interest }\end{array}$} & \multirow[t]{3}{*}{$\begin{array}{l}\text { Limited land } \\
\text { transformation }\end{array}$} \\
\hline & & $\begin{array}{l}\text { Positive impact } \\
\text { due to reshaping } \\
\text { and replanting } \\
\text { works on } \\
\text { discharge } \\
\text { location }\end{array}$ & No measure & & \\
\hline & & $\begin{array}{l}0,4 \text { ha of } \\
\text { potential } \\
\text { wetland of low } \\
\text { interest will be } \\
\text { transformed }\end{array}$ & $\begin{array}{l}0,85 \text { ha of area } \\
\text { maintained as } \\
\text { wild land } \\
\text { (rehabilitation) }\end{array}$ & & \\
\hline $\begin{array}{l}\text { Impacts on the site } \\
\text { during operation } \\
\text { (EIA - step 3-b3) }\end{array}$ & $\begin{array}{l}\text { Odor, noise, } \\
\text { landscape, } \\
\text { land } \\
\text { occupation, } \\
\text { service road } \\
\& \text { traffic, } \\
\text { natural } \\
\text { environment } \\
\text {, and } \\
\text { groundwater } \\
\text { pollution }\end{array}$ & $\begin{array}{l}\text { No significant } \\
\text { impacts, except } \\
\text { odor near } \\
\text { stormwater } \\
\text { overflows }\end{array}$ & No measure & $\begin{array}{l}\text { Impact on } \\
\text { wetland } \\
\text { landscape }\end{array}$ & $\begin{array}{l}\text { Chalet type buried } \\
\text { construction work }\end{array}$ \\
\hline $\begin{array}{l}\text { Impacts due to } \\
\text { extreme climatic } \\
\text { or water events }\end{array}$ & $\begin{array}{l}\text { Frost/Storm/ } \\
\text { Flood }\end{array}$ & $\begin{array}{l}\text { Storm: Direct } \\
\text { release in the } \\
\text { natural } \\
\text { environment in } \\
\text { case of power } \\
\text { cut }\end{array}$ & $\begin{array}{l}\text { Remote } \\
\text { management } \\
\text { system }\end{array}$ & $\begin{array}{l}\text { Direct } \\
\text { release in the } \\
\text { natural } \\
\text { environment } \\
\text { in case of } \\
\text { power cut }\end{array}$ & $\begin{array}{l}\text { Remote management } \\
\text { system }\end{array}$ \\
\hline Sanitary impacts & $\begin{array}{l}\text { Microbial, } \\
\text { chemical } \\
\text { and physical } \\
\text { impacts via } \\
\text { Surface } \\
\text { water/Air/ } \\
\text { Groundwater }\end{array}$ & $\begin{array}{l}\text { Air: no } \\
\text { propagation of } \\
\text { aerosols (except } \\
\text { for personnel) } \\
\text { due to quantities } \\
\text { and distances } \\
\text { Water: Low } \\
\text { microbial risks }\end{array}$ & $\begin{array}{l}\text { Prevent water } \\
\text { stagnation } \\
\text { with the } \\
\text { reshaping }\end{array}$ & None & No measure \\
\hline
\end{tabular}


Author-produced version of the article published in Environmental Impact Assessment Review, 2017, №63, p. 95-106.

The original publication is available at http://www.sciencedirect.com

http://dx.doi.org/10.1016/j.eiar.2016.12.004

Table S 4: Reorganisation of the issues and associated impacts

\begin{tabular}{|c|c|c|c|}
\hline $\begin{array}{c}\text { General } \\
\text { issues }\end{array}$ & Detailed issues & Impacts & $\begin{array}{l}\text { Paragraph dealing with this } \\
\text { aspect in the EIA report }\end{array}$ \\
\hline \multirow{4}{*}{ WATER-USE } & Change on water flows - Operation & $\begin{array}{l}\text { Impact on Human } \\
\text { Health and } \\
\text { Ecosystems }\end{array}$ & $\begin{array}{l}\text { Impact on the receiving } \\
\text { environment }>\text { Impact on flows }\end{array}$ \\
\hline & \multirow{3}{*}{ Water pollution - Operation } & $\begin{array}{l}\text { Impact on Human } \\
\text { Health } \\
\text { (Toxicity) }\end{array}$ & $\begin{array}{l}\text { Health section } \\
>\text { Microbial and chemical impacts }\end{array}$ \\
\hline & & \multirow[t]{2}{*}{$\begin{array}{l}\text { Impact on } \\
\text { Ecosystems } \\
\text { (Ecotoxicity) }\end{array}$} & $\begin{array}{l}\text { Impact on the receiving } \\
\text { environment } \\
\text { > Impacts in dry weather } \\
\text { + Impacts in wet weather } \\
\text { + Impacts during civil works }\end{array}$ \\
\hline & & & $\begin{array}{l}\text { Impact on the implantation site } \\
\text { > Impacts of operation } \\
\text { (groundwater) }\end{array}$ \\
\hline \multirow[b]{2}{*}{ LAND-USE } & Land transformation - Construction & $\begin{array}{l}\text { Impact on } \\
\text { Ecosystems }\end{array}$ & $\begin{array}{l}\text { Impact on the implantation site } \\
\text { > Impacts of construction }\end{array}$ \\
\hline & Land occupation - Operation & $\begin{array}{l}\text { Impact on } \\
\text { Ecosystems }\end{array}$ & $\begin{array}{l}\text { Impact on the implantation site } \\
\text { > Impacts of operation } \\
\text { > Soil occupation } \\
\text { + Impact on the natural } \\
\text { environment (fauna \& flora) }\end{array}$ \\
\hline AIR & Air pollution - Operation & $\begin{array}{l}\text { Impact on Human } \\
\text { Health }\end{array}$ & Health section > Microbial impacts \\
\hline \multirow{7}{*}{ NUISANCES } & Noise - Construction & $\begin{array}{l}\text { Impact on Human } \\
\text { Health and Social } \\
\text { Impact }\end{array}$ & $\begin{array}{l}\text { Impact on the implantation site } \\
>\text { Impacts of operation }\end{array}$ \\
\hline & \multirow{2}{*}{ Noise - Operation } & \multirow{2}{*}{$\begin{array}{l}\text { Impact on Human } \\
\text { Health }\end{array}$} & $\begin{array}{l}\text { Impact on the implantation site } \\
\text { > Impacts of operation }\end{array}$ \\
\hline & & & $\begin{array}{l}\text { Health section } \\
>\text { Physical impacts }\end{array}$ \\
\hline & Service road \& traffic - Operation & Social Impact & $\begin{array}{l}\text { Impact on the implantation site } \\
\text { > Impacts of operation }\end{array}$ \\
\hline & Odor - Operation & Social Impact & $\begin{array}{l}\text { Impact on the implantation site } \\
\text { > Impacts of operation }\end{array}$ \\
\hline & Light pollution - Operation & $\begin{array}{l}\text { Impact on Human } \\
\text { Health }\end{array}$ & $\begin{array}{l}\text { Health section } \\
>\text { Physical impacts }\end{array}$ \\
\hline & Landscape - Operation & Social Impact & $\begin{array}{l}\text { Impact on the implantation site } \\
\text { > Impacts of operation }\end{array}$ \\
\hline
\end{tabular}

815

816 


\begin{tabular}{|c|c|c|c|c|}
\hline & WWTP model & $\begin{array}{l}\text { Population } \\
\text { Equivalent }\end{array}$ & $\begin{array}{l}\text { LCI } \\
\text { sources }\end{array}$ & Comments \\
\hline \multirow[b]{2}{*}{$\begin{array}{l}\text { Case } \\
\text { study } 1\end{array}$} & AS1 / AS-SBR1 & 440 & (1) (2) & $\begin{array}{l}\text { LCI model adapted and extrapolated from a } \\
5200 \text { p.e. AS*. }\end{array}$ \\
\hline & vRBF1 & 440 & $\begin{array}{l}\text { (1) (3) (4) } \\
\text { (5) }(6)(7)\end{array}$ & $\begin{array}{l}\text { For the impact assessment (step 4), the LCI } \\
\text { model was adapted using data available in the } \\
\text { EIA study } 1 \text {. }\end{array}$ \\
\hline \multirow{5}{*}{$\begin{array}{l}\text { Case } \\
\text { study } 2\end{array}$} & AL2 & 684 & (10) (11) & \\
\hline & AS2 / AS-SBR2 & 684 & $\begin{array}{l}\text { (1) (2) } \\
(12)\end{array}$ & $\begin{array}{l}\text { LCI model adapted and extrapolated from a } \\
5200 \text { p.e. AS*. } \\
\text { For the impact assessment (step 4), the model } \\
\text { was adapted using data available in the EIA } \\
\text { study } 2 \text {. }\end{array}$ \\
\hline & hRBF2 & 684 & $\begin{array}{lll}(1) & (3) & (4) \\
(5) & (6) & (7) \\
(8) & & \end{array}$ & \\
\hline & vRBF2 & 684 & $\begin{array}{l}\text { (1) (3) (4) } \\
(5)(6)(7)\end{array}$ & \\
\hline & NL2 & 684 & $\begin{array}{l}\text { (3) }(6) \quad(9) \\
(10)(11)\end{array}$ & \\
\hline
\end{tabular}

(1) (Risch et al., 2014); (2) (Risch et al., 2015); (3) (Boutin et al., 2007); (4) (EPNAC, 2015); (5) (Macrophytes et Traitement des Eaux, 2005); (6) (Liénard et al., 2004); (7) (M.A.G.E. 42, 2007); (8) (Molle et al., 2008); (9) (Racault et al., 1997); (10) (Alexandre et al., 1998); (11) (von Sperling, 2007); (12) (SDEA, 2013)

*For the same capacity range of WWTP the chosen FU allows a consistent extrapolation of the results for other capacity. The following adaptations were made: no chemical treatment to remove phosphate, all sludge considered to be used in agriculture. 
Author-produced version of the article published in Environmental Impact Assessment Review, 2017, №63, p. 95-106

Table S 6: Selected inventory data for the WWTP model

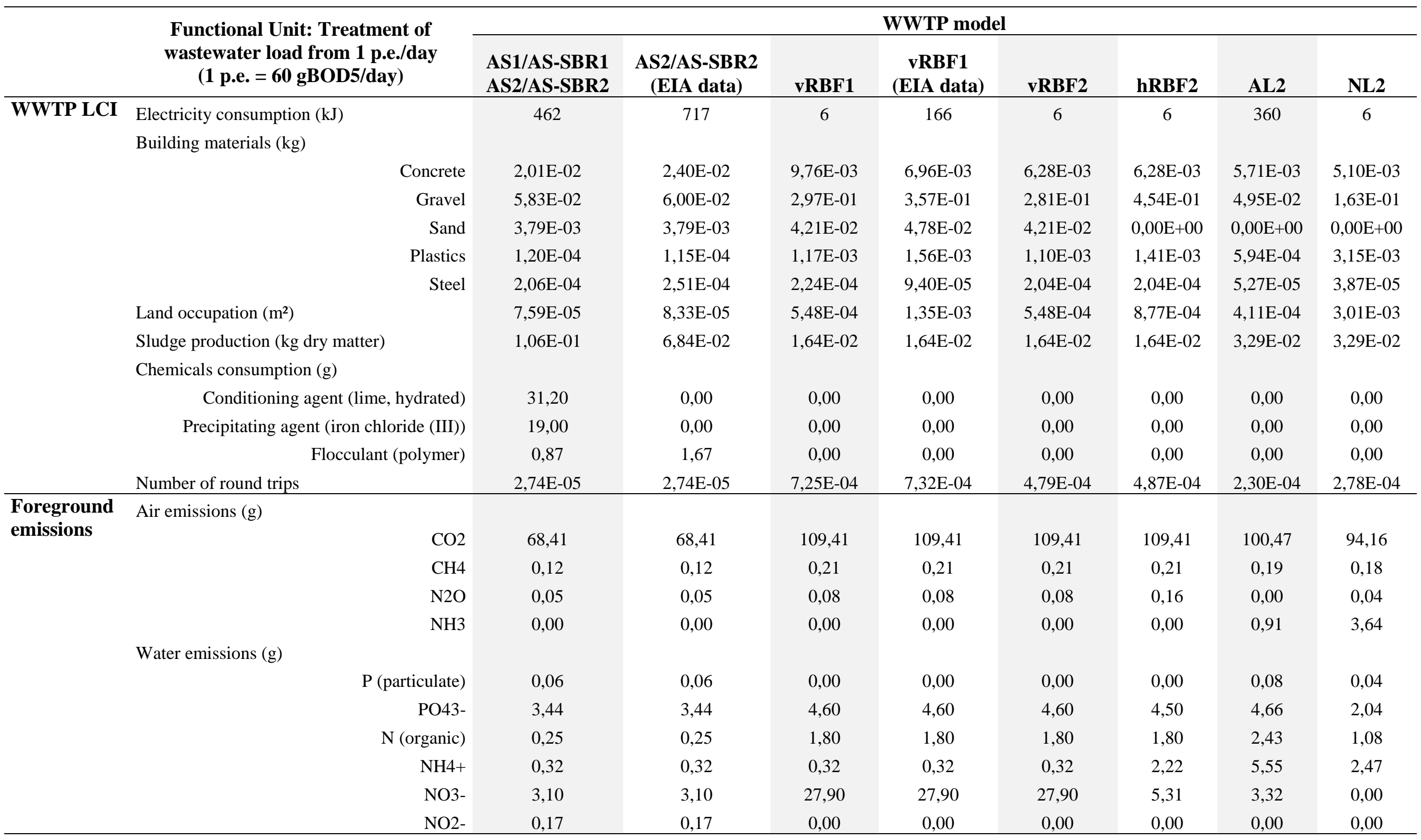


Table S 7: Description of the implementation of mitigation measures modelled (LCI)

\begin{tabular}{|c|c|c|c|}
\hline & $\begin{array}{l}\text { Mitigated } \\
\text { impacts }\end{array}$ & Mitigation measures & $\begin{array}{l}\text { Hypotheses for the LCI of the } \\
\text { implementation of the measures }\end{array}$ \\
\hline \multirow{5}{*}{$\begin{array}{c}\text { Case } \\
\text { study } 1\end{array}$} & \multirow{3}{*}{$\begin{array}{l}\text { Change in } \\
\text { water flows } \\
\text { and pollution }\end{array}$} & $\begin{array}{l}\text { a) Reshaping the ditch to } \\
\text { improve water flow: on } 100 \mathrm{~m} \\
\text { b) Maintenance/ditch cleaning }\end{array}$ & $\begin{array}{l}\text { a) Civil engineering works : } 2 \text { days (16h) of } \\
\text { excavator and dump truck } \\
\text { b) Civil engineering works : } 4 \text { h of excavator } \\
\text { and dump truck once a year } \\
\text { (WWTP lifetime }=30 \text { years) }\end{array}$ \\
\hline & & Plant sizing (no details) & No change in WWTP operation modelling \\
\hline & & $\begin{array}{l}\text { Operation from river banks and } \\
\text { excavated area reconditioning }\end{array}$ & $\begin{array}{l}\text { Already modelled in LCI } \\
\text { (generic modelling of construction) }\end{array}$ \\
\hline & $\begin{array}{l}\text { Land } \\
\text { transformation }\end{array}$ & $\begin{array}{l}\text { a) Clay plugs within unsorted } \\
\text { material layer } \\
\text { b-1) Riverbank reprofiling and } \\
\text { revegetation }(100 \mathrm{~m}) \\
\text { b-2) Return to the natural state } \\
\text { of } 0.85 \text { ha of land }\end{array}$ & $\begin{array}{l}\text { a) Unsorted material layer was not modelled; thus } \\
\text { nor is clay } \\
\text { b-1) Benefit not quantifiable in LCIA } \\
\text { b-2) Supposed ecological equilibrium with } \\
\text { destroyed wetland - Poor consideration of land } \\
\text { transformation impacts in LCIA }\end{array}$ \\
\hline & Odour & Canal cleaning & $\begin{array}{l}\text { Civil engineering works : } 1 \text { week }(40 \mathrm{~h}) \text { of } \\
\text { excavator and dump truck }\end{array}$ \\
\hline \multirow{4}{*}{$\begin{array}{c}\text { Case } \\
\text { study } 2\end{array}$} & \multirow{2}{*}{$\begin{array}{l}\text { Change in } \\
\text { water flows } \\
\text { and pollution }\end{array}$} & Sludge blanket detector & $\begin{array}{l}\text { WWTP small electronic equipment not modelled; } \\
\text { thus nor is this detector }\end{array}$ \\
\hline & & $\begin{array}{l}\text { Operation from river banks and } \\
\text { excavated area reconditioning }\end{array}$ & $\begin{array}{l}\text { Already modelled in LCI } \\
\text { (generic modelling of construction) }\end{array}$ \\
\hline & $\begin{array}{l}\text { Land } \\
\text { transformation }\end{array}$ & $\begin{array}{l}\text { Positioning installation in less } \\
\text { sensitive areas (location) }\end{array}$ & $\begin{array}{l}\text { Already modelled in LCI } \\
\text { (generic modelling of construction) }\end{array}$ \\
\hline & Landscape & $\begin{array}{l}\text { Landscape integration via chalet } \\
\text { type buried construction work }\end{array}$ & $\begin{array}{l}\text { Already modelled in LCI } \\
\text { (generic modelling of construction) }\end{array}$ \\
\hline Fine & estruction of ordin & $\begin{array}{l}\text { ary wetland area has a mitigation rat } \\
\text { sure for the destruction of } 0.4 \text { ha of ord } \\
\text { the recolonisation of land by charact }\end{array}$ & $\begin{array}{l}\text { tio of } 2 \text { (Inter-Services Water Mission MISE report). } \\
\text { dinary wetland is to leave fallow } 0.85 \text { ha of land to allow } \\
\text { teristic species of wetland. }\end{array}$ \\
\hline
\end{tabular}


Author-produced version of the article published in Environmental Impact Assessment Review, 2017, №63, p. 95-106. The original publication is available at http://www.sciencedirect.com

http://dx.doi.org/10.1016/j.eiar.2016.12.004

Table S 8: Issues considered within the existing EIA and proposed rating for the two case studies

\begin{tabular}{|c|c|c|c|c|}
\hline \multirow{2}{*}{$\begin{array}{c}\text { Issues }^{(1)} \text { considered in } \\
\text { existing EIA }\end{array}$} & \multicolumn{2}{|l|}{ Case Study 1 (CS1) - Qualification / Rating in EIA } & \multicolumn{2}{|l|}{ Case Study 2 (CS2) - Qualification / Rating in EIA } \\
\hline & Low waterflow, Mitigation measure to improve waterflow & 2 & WWTP flow insignificant, No measure & 0 \\
\hline $\begin{array}{l}\text { Water pollution - Operation - } \\
\text { HH }\end{array}$ & $\begin{array}{c}\text { Microbial: No recreational use of the receiving environment, } \\
\text { negligible risk }\end{array}$ & 0 & $\begin{array}{c}\text { Microbial: No recreational use of the receiving environment, } \\
\text { negligible risk } \\
\text { Chemical: no use of chemical products for the treatment, zero risk }\end{array}$ & 0 \\
\hline \multirow[t]{2}{*}{$\begin{array}{l}\text { Water pollution - Operation - } \\
\qquad \mathrm{E}\end{array}$} & $\begin{array}{l}\text { Dry weather: Stream downgrading, Measure (plant sizing): } 2 \\
\text { Wet weather: Non negligible impact, Measure (plant sizing): } 2 \\
\text { Civil engineering works: No major impact but risks of suspended } \\
\text { matter, Measure (excavated area reconditioning): } 2\end{array}$ & 2 & $\begin{array}{c}\text { Dry/Wet weather: Stream downgrading, Measure (sludge blanket } \\
\text { detector): } 2 \\
\text { Civil engineering works: Risk of suspended matter, Measure } \\
\text { (operation from river banks): } 2\end{array}$ & 2 \\
\hline & Infiltration risk negligible: no groundwater pollution & 0 & No groundwater pollution & 0 \\
\hline Air pollution - Operation $-\mathrm{HH}$ & $\begin{array}{l}\text { Risk negligible due to (i) low aerosol quantities (ii) large distances } \\
\text { with surrounding habitations }\end{array}$ & 0 & $\begin{array}{l}\text { Risk negligible due to (i) low aerosol quantities (ii) large distances } \\
\text { with surrounding habitations }\end{array}$ & 0 \\
\hline $\begin{array}{l}\text { Land transformation - } \\
\quad \text { Construction - E }\end{array}$ & $\begin{array}{c}\text { 1) Indirect impact on a remarkable }{ }^{(2)} \text { wetland + Measure to avoid } \\
\text { drainage } \\
\begin{array}{c}\text { 2) Destruction of ordinary }{ }^{(2)} \text { wetland area (0.4ha) - Mitigation } \\
\text { measure (rehabilitation) }\end{array}\end{array}$ & 2 & $\begin{array}{l}\text { Irremediable effect (zone Natura 2000), but non-significant }(<0.01 \% \\
\text { of the Natura } 2000 \text { site) and no habitats of community interest, } \\
\text { Measure (positioning installation in less sensitive areas) }\end{array}$ & 2 \\
\hline $\begin{array}{c}\text { Land occupation }- \text { Operation } \\
-E\end{array}$ & Insignificant ground footprint on agricultural area & 0 & Insignificant ground footprint on pasture area & 0 \\
\hline $\begin{array}{c}\text { Noise }- \text { Construction }-\mathrm{HH} \& \\
\mathrm{~S}\end{array}$ & Noise, No measure & 1 & Noise, No measure & 1 \\
\hline Noise - Operation $-\mathrm{HH}$ & $\begin{array}{c}\text { No disturbing noise / } \\
\text { Few health risks from noise }\end{array}$ & 0 & $\begin{array}{l}\text { Limited noise nuisance / } \\
\text { Few health risks from noise }\end{array}$ & 0 \\
\hline Traffic - Operation $-\mathrm{S}$ & No impact & 0 & Impact negligible & 0 \\
\hline Odor - Operation $-\mathrm{S}$ & $\begin{array}{l}\text { One of the most sensitive aspects: 1) Stormwater overflows: odor } \\
\text { risk, 2) Pumping station/Plant: limited risk, Measure (cleaning } \\
\text { work on the canal, but no measure on the plant site) }\end{array}$ & 1 & Limited odor nuisance & 0 \\
\hline $\begin{array}{c}\text { Light pollution - Operation - } \\
\text { HH }\end{array}$ & No impact mentioned & 0 & No impact mentioned & 0 \\
\hline Landscape - Operation $-\mathrm{S}$ & Impact very limited, No measure & 0 & $\begin{array}{l}\text { 1) Landscape disturbance (near Natura 2000, discontinuity with the } \\
\text { urbanised area), Measure (landscape integration via chalet type buried } \\
\text { construction work) }\end{array}$ & 2 \\
\hline
\end{tabular}

(1) Impacts on Human Health (HH), Ecosystems (E) and Societal issues (S) construction work) 


\section{List of Figures}

Figure S 1: Endpoint impacts of the theoretical alternatives for case study 1

Figure S 2: Midpoint impacts of the theoretical alternatives for case study 1

Figure S 3: Midpoint impacts of the theoretical alternatives for case study 2

Figure S 4: Contributions to the endpoint Human Health for case study 1 (left) and case study 2 (right).

Figure S 5: Contributions to the endpoint Ecosystems for case study 1 (left) and case study 2 (right).

Figure S 6: Contributions to the endpoint Resources for case study 1 (left) and case study 2 (right).

Figure S 7: Main concerns exposed based on LCA endpoint indicators for case study 2 ....... 42 Figure S 8: Contribution of the impacts of the implementation of mitigation measures to the entire WWTP impacts for case study 1 (midpoint indicators)

Figure S 9: Contribution of the impacts of the implementation of mitigation measures to the entire WWTP impacts for case study 1 (endpoint indicators)

Legend for Figure S 1, Figure S 2 and Figure S 3:

$A S=$ Activated Sludge and AS-SBR=Activated Sludge Sequencing Batch Reactor $/ v R B F=$ vertical Reed Bed Filters $/ \mathrm{hRBF}$ $=$ horizontal Reed Bed Filters $/ N L=$ Naturally Aerated Lagoons $/ A L=$ Artificially Aerated Lagoons

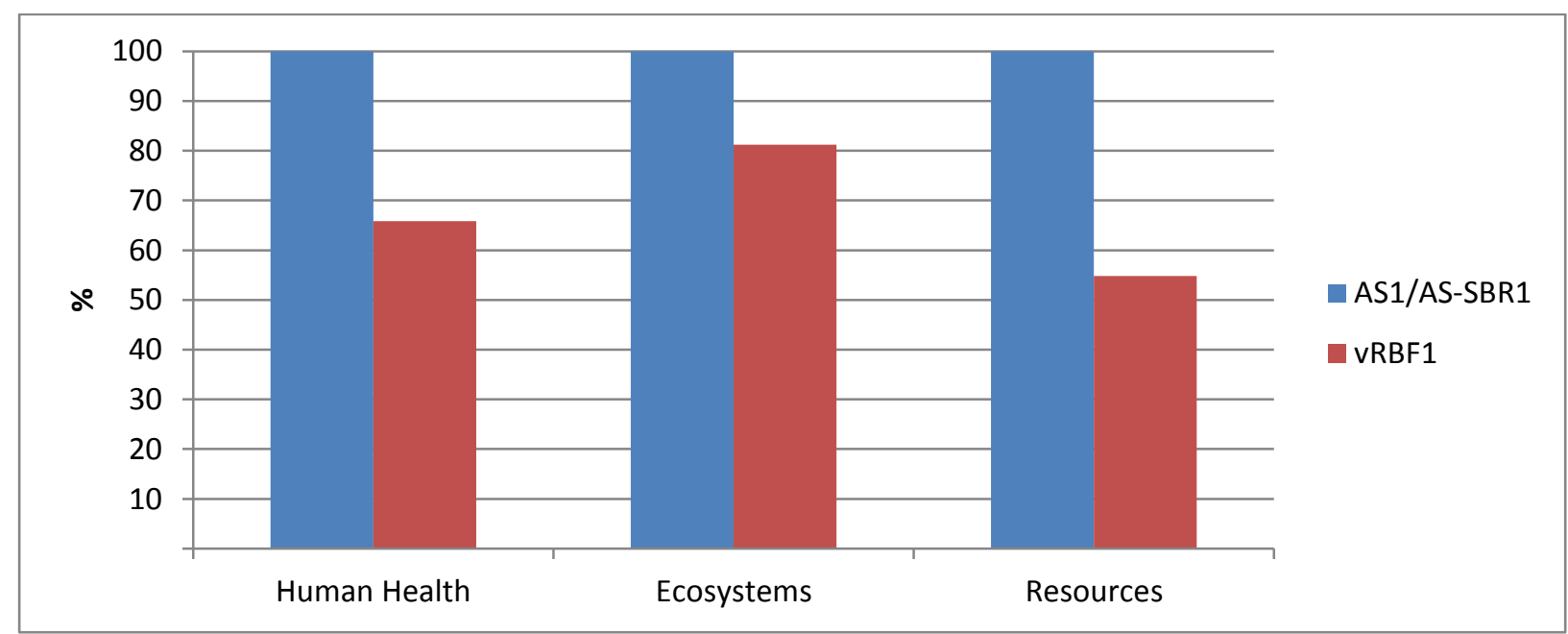

Figure S 1: Endpoint impacts of the theoretical alternatives for case study 1 


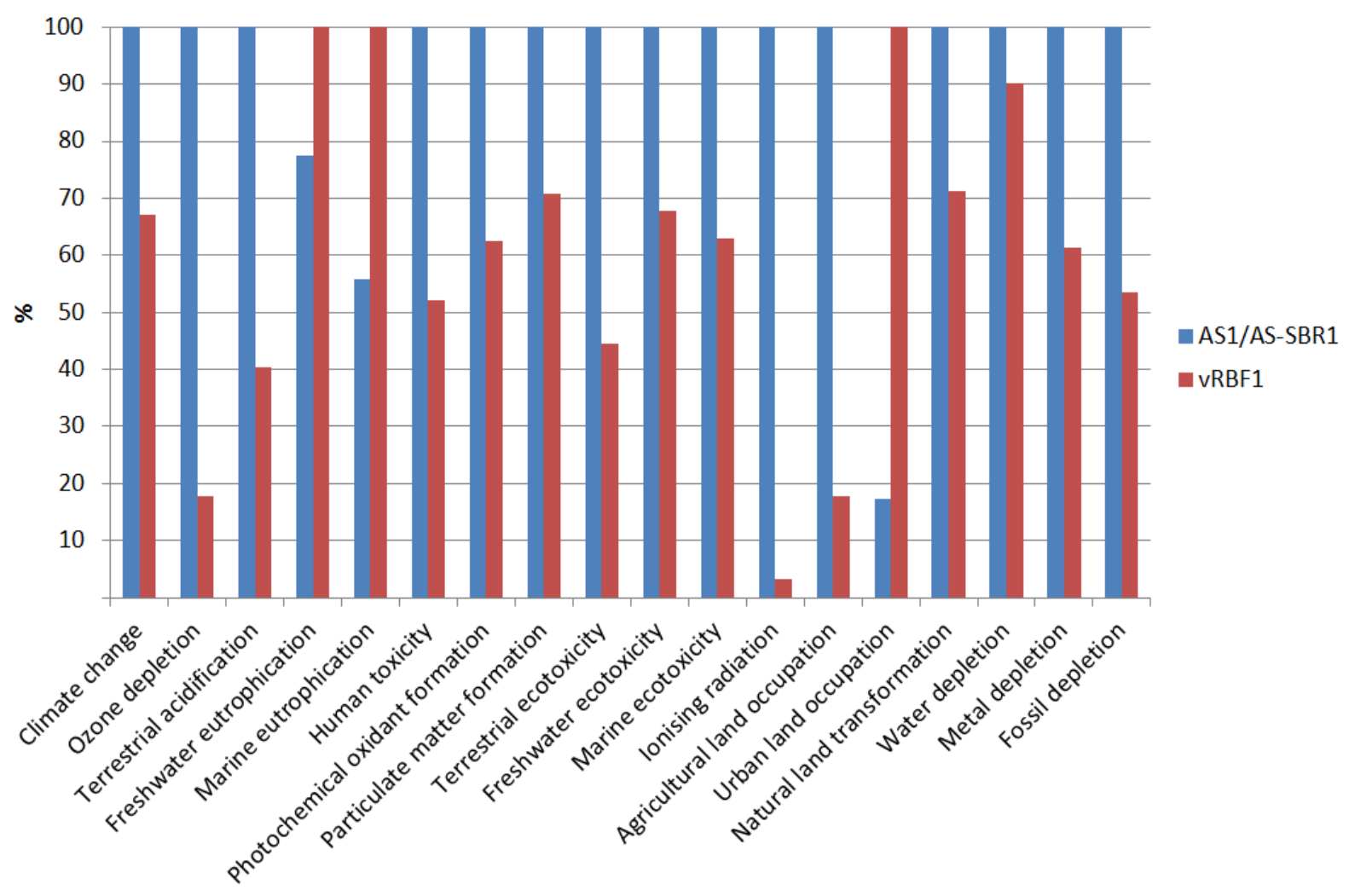

Figure S 2: Midpoint impacts of the theoretical alternatives for case study 1
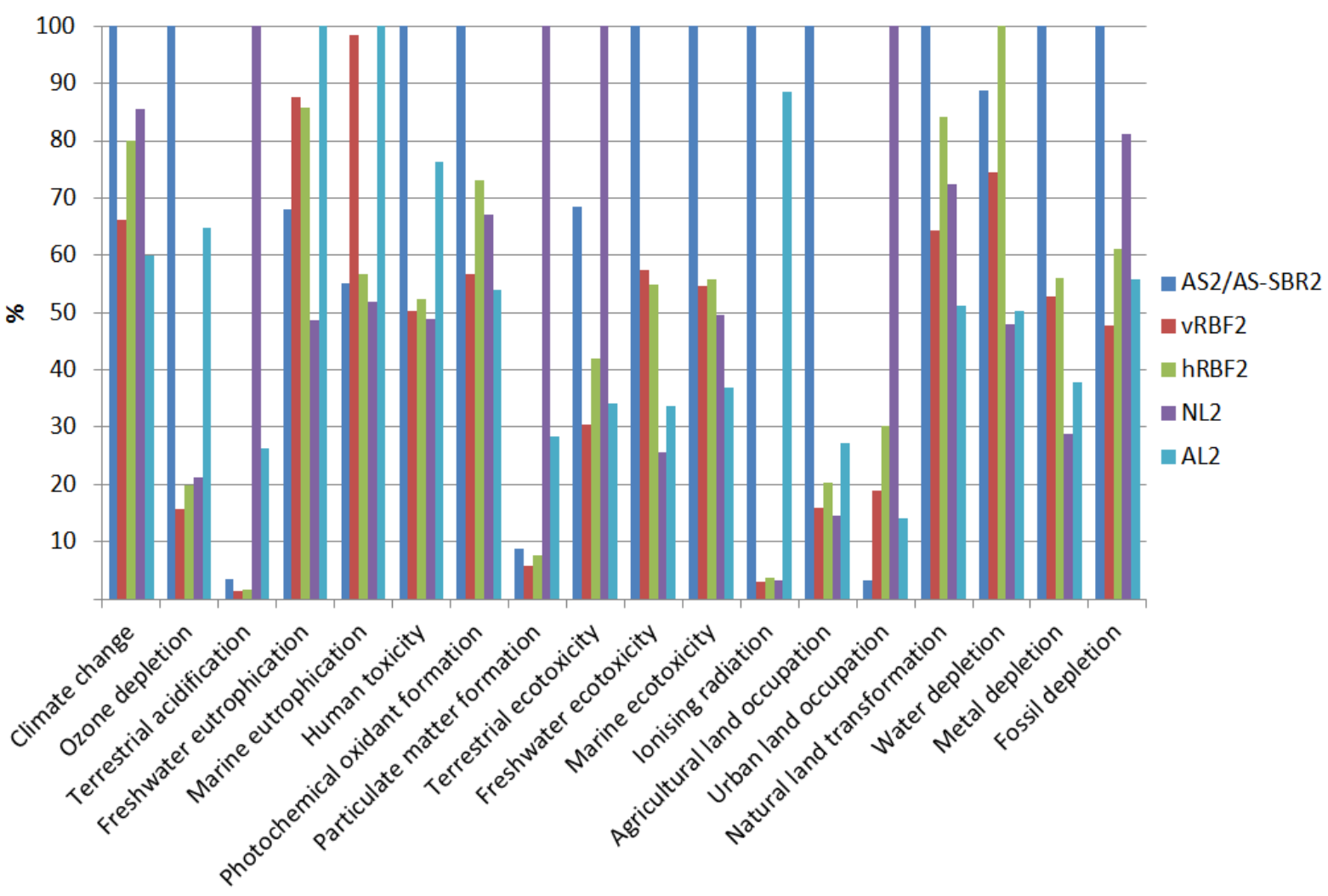

Figure S 3: Midpoint impacts of the theoretical alternatives for case study 2 
CS 1

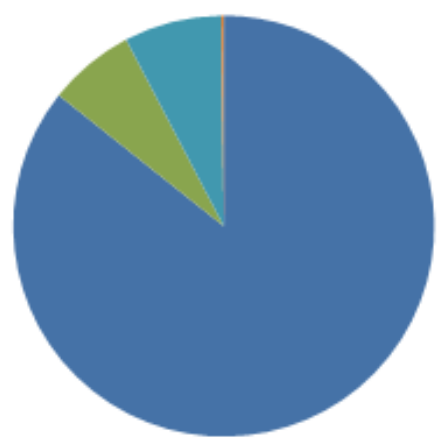

CS 2

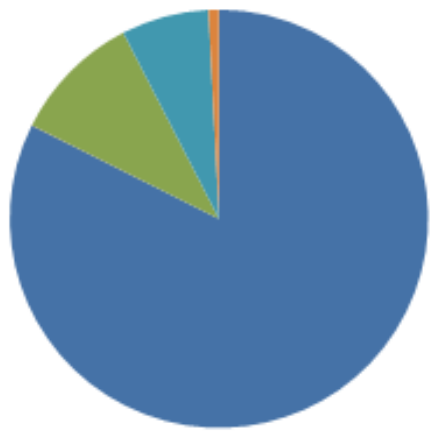

- Climate change Human Health

- Ozone depletion

Human toxicity

- Photochemical oxidant formation

口 Particulate matter formation

- lonising radiation

Figure S 4: Contributions to the endpoint Human Health for case study 1 (left) and case study 2 (right)

CS 1

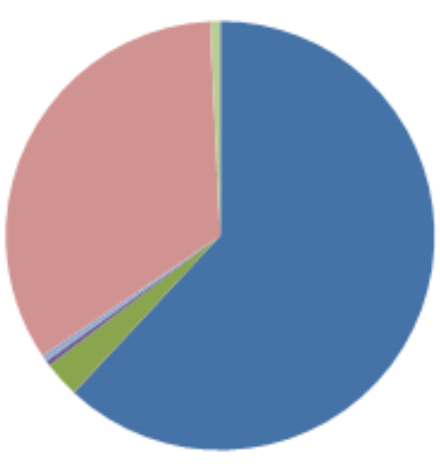

\section{CS 2}

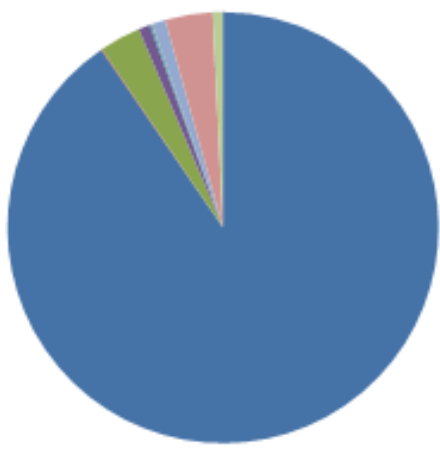

- Climate change Ecosystems

- Terrestrial acidification

Freshwater eutrophication

Terrestrial ecotoxicity

Freshwater ecotoxicity

Marine ecotoxicity

Agricultural land occupation

- Urban land occupation

- Natural land transformation

Figure S 5: Contributions to the endpoint Ecosystems for case study 1 (left) and case study 2 (right)

CS 1

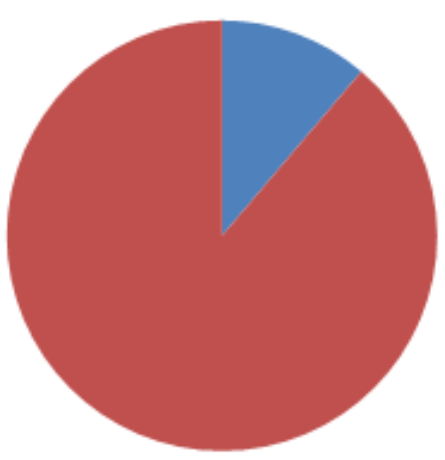

CS 2

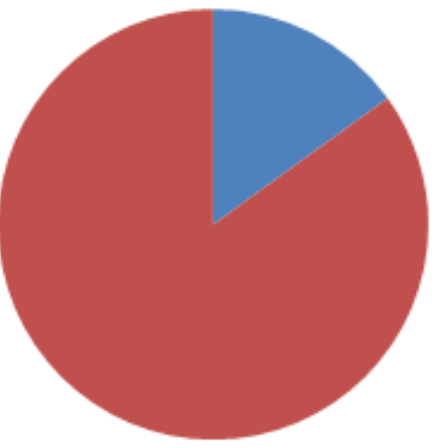

Metal depletion

Fossil depletion

Figure S 6: Contributions to the endpoint Resources for case study 1 (left) and case study 2 (right) 
Author-produced version of the article published in Environmental Impact Assessment Review, 2017, №63, p. 95-106.

The original publication is available at http://www.sciencedirect.com http://dx.doi.org/10.1016/j.eiar.2016.12.004

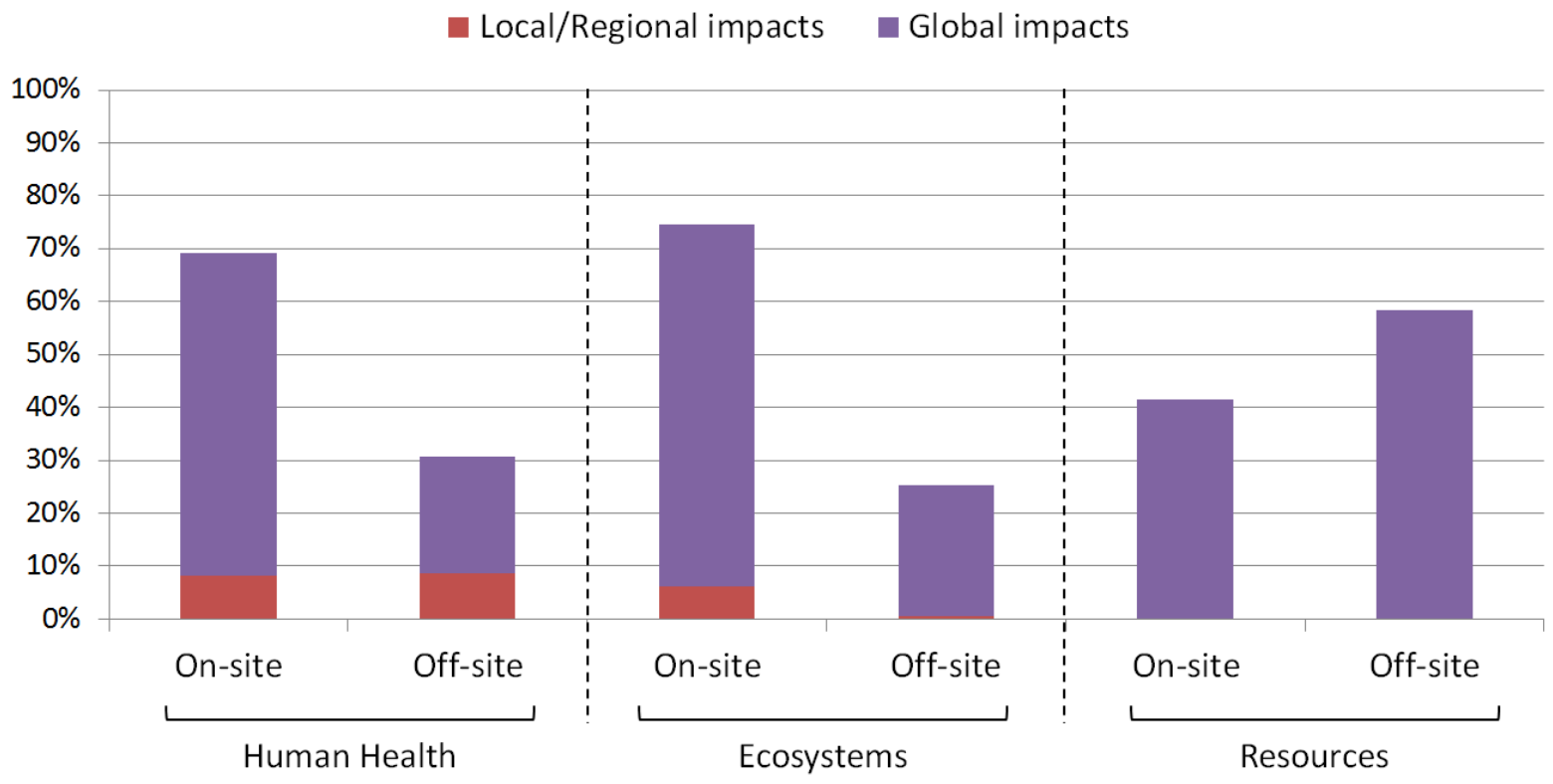

Figure S 7: Main concerns exposed based on LCA endpoint indicators for case study 2

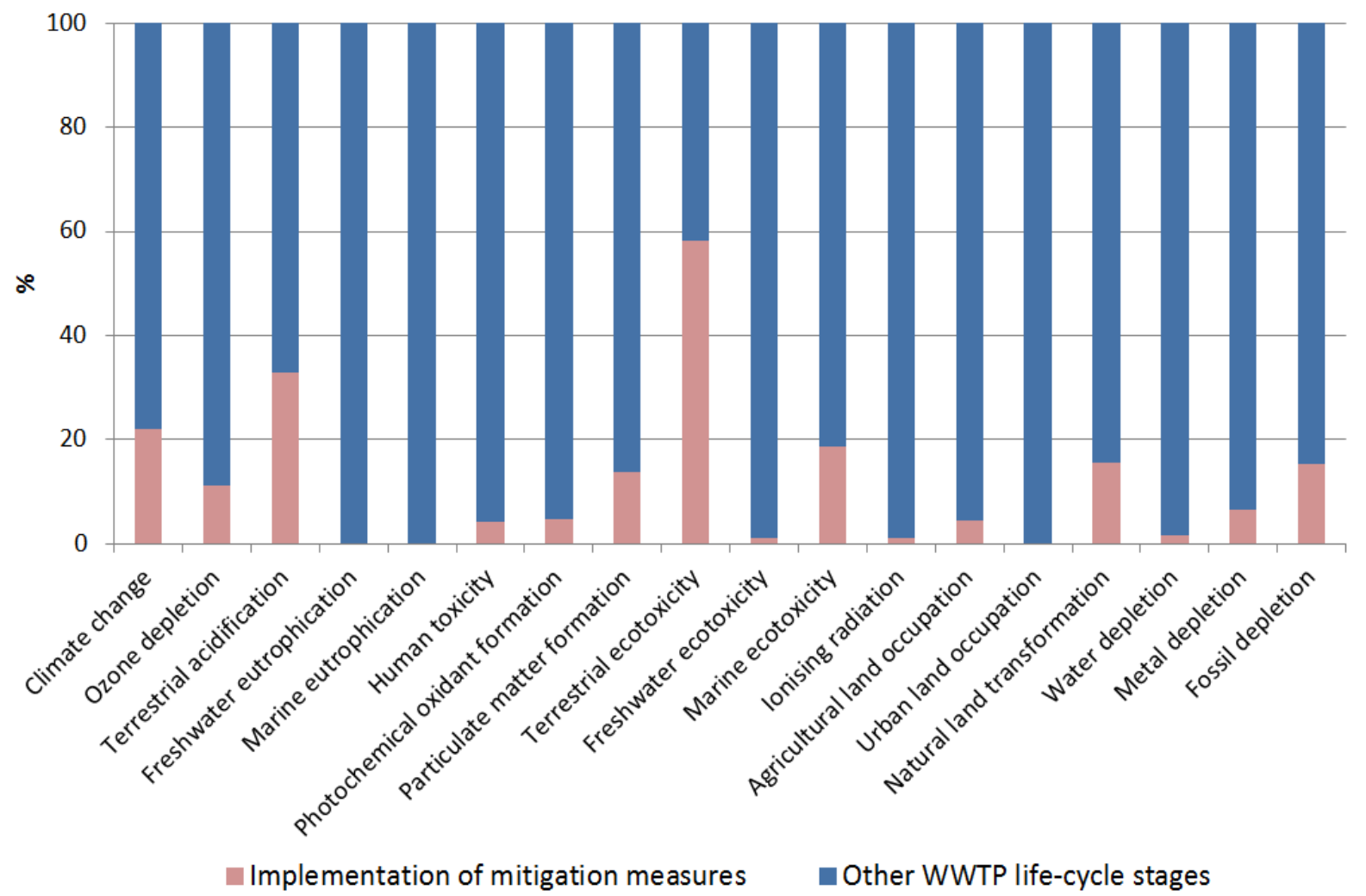

Figure S 8: Contribution of the impacts of the implementation of mitigation measures to the entire WWTP impacts for case study 1 (midpoint indicators) 


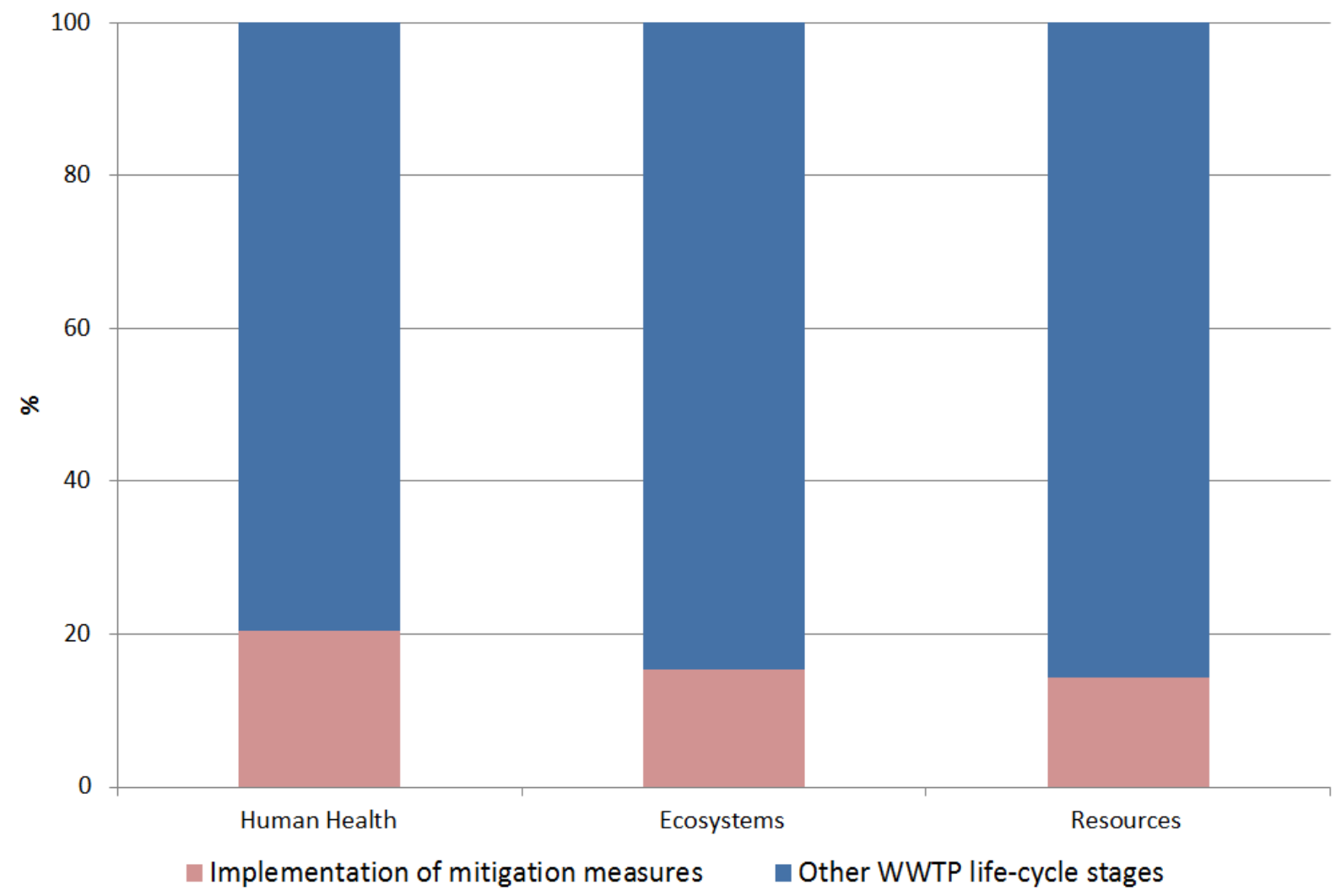

Figure S 9: Contribution of the impacts of the implementation of mitigation measures to the entire WWTP impacts for case study 1 (endpoint indicators) 


\section{Vitae Authors}

\section{1) Pyrène Larrey-Lassalle}

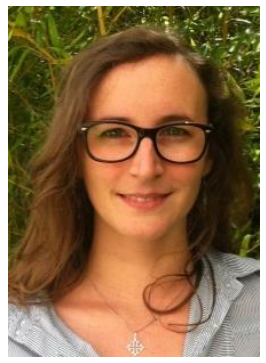

Pyrène Larrey-Lassalle is engineer in environmental processes from the National Institute of Applied Sciences (INSA) of Toulouse, France. After managing and carrying out different industrial and institutional research projects in Life Cycle Assessment (LCA), she decided to pursue doctoral studies on the convergence of environmental assessment methods, at the French research institutes Irstea Montpellier and Ecole des Mines d'Alès. Her $\mathrm{PhD}$ is funded by the Industrial Research Chair ELSA-PACT. Her research focuses on the complementarity between EIA and LCA, and she is particularly interested in the improvement of land-use impacts on biodiversity assessment for both these approaches.

\section{2) Laureline Catel}

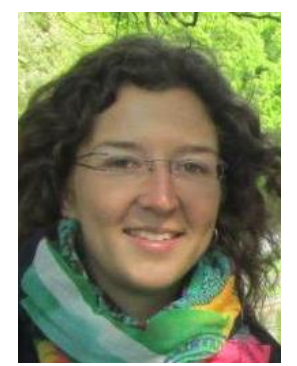

Laureline Catel is an agronomist from Montpellier SupAgro (France) specialized in the management of water and environment. She joined Irstea (French National Research Institute of Science and Technology for Environment and Agriculture) and the ELSA research group as a research engineer in the field of Life Cycle Assessment (LCA) applied to urban water systems and especially to wastewater systems. Her main mission is to improve LCA applicability through the development of simplified LCA tools for water systems.

\section{3) Philippe Roux}

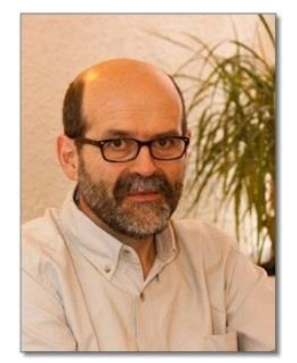

Philippe Roux, 55 years old, MS in Process Engineering (1992) and Mechanical Engineer (1985) working at Irstea since 1989 (French National Research Institute of Science and Technology for Environment and 
Agriculture). Research engineer in the field of Life Cycle Assessment, Philippe is the leader of the ELSA-Itap team and the co-founder of the ELSA research group. He has been involved in many research projects (European, French ANR, Chaire Elsa-Pact, etc.) and is the co-author of 44 scientific publications. He has knowledge in several application fields: agriculture, agricultural equipment, greenhouses, pesticide application techniques, forestry, water \& wastewater.

www.researchgate.net/profile/Philippe_Roux

www1.montpellier.inra.fr/elsa

\section{4) Ralph K. Rosenbaum}

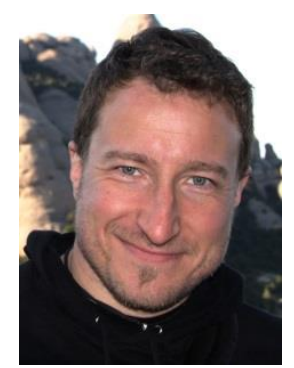

Ralph K. Rosenbaum is an environmental modeller and expert for life cycle assessment with an environmental engineering degree from the Technical University Berlin, Germany and a Ph.D. from the Swiss Federal Institute of Technology Lausanne (EPFL). As the Director of the Industrial Chair for Environmental and Social Sustainability Assessment "ELSA-PACT" at the French National Research Institute of Science and Technology for Environment and Agriculture (Irstea) in Montpellier, France, his current research focuses on environmental impact modelling of emissions and resource use such as water or soil.

\section{5) Miguel Lopez-Ferber}

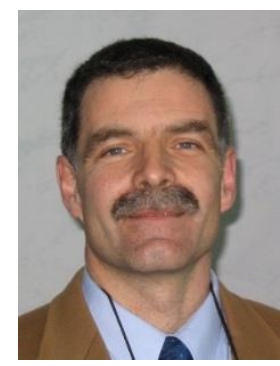

Miguel Lopez-Ferber is professor of environmental engineering at the Laboratory of Environmental Engineering of the Ecole des mines d'Alès. After a PhD on Pathology and Parasitology, he worked on the reduction of chemical pesticide pollution by developing bio-insecticides. His present research aims to analyse the interactions between organisms or groups and the main drivers conditioning the final response (antagonisms, synergies ...), both from the Biological Ecology and from the Industrial Ecology perspectives.

\section{6) Guillaume Junqua}




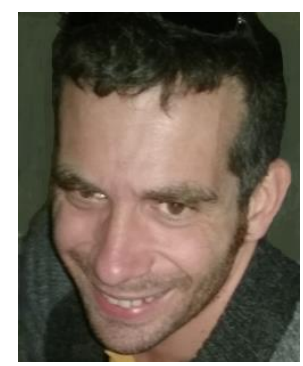

Guillaume Junqua is an Assistant Professor of industrial ecology at the industrial and environmental engineering Laboratory of Ecole des mines d'Alès, France. His research focuses on the implementation and assessment of industrial symbioses on harbour areas, integrating both human (characterization of stakeholders' needs, skills, interactions, and representations) and technical (material flow analysis and environmental assessment) approaches, and taking into account different temporal and spatial scales.

\section{7) Eléonore Loiseau}

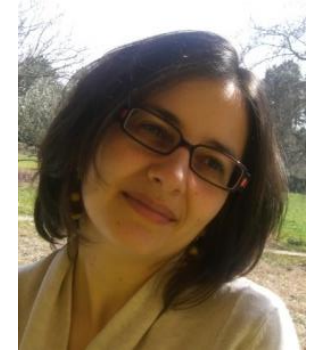

Eléonore Loiseau graduated from AgroParisTech (Master's degree, 2008) and AgroParisTech - Engref (PostMaster degree for Management and Administration in environmental sciences and policies, 2010). She obtained her PhD in process engineering on the field of LCA in 2014. Her work was focused on methodological proposals for performing an environmental assessment of territories based on the LCA framework. Still working in ELSA (Environmental Lifecycle and Sustainability Assessment) team, she is now a research engineer at Irstea (UMR Itap) where she is continuing her research on "territorial LCA" and industrial ecology approaches. 